\title{
La mediación
} en el campo informativo documental

\author{
MIGUEL ÁNGEL \\ RENDÓN ROJAS
} Coordinador

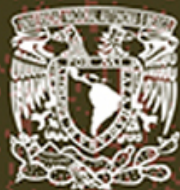




\section{La presente obra está bajo una licencia de:}

\section{http://creativecommons.org/licenses/by-nc-sa/3.0/deed.es MX}

\section{Atribución-No Comercial-Licenciamiento Reciproco 3.0 Unported}

Eres libre de:

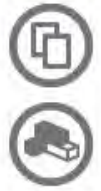

copiar, distribuir y comunicar públicamente la obra

hacer obras derivadas

Bajo las condiciones siguientes:

Atribución - Debes reconocer la autoría de la obra en los términos

especificados por el propio autor o licenciante.

No comercial - No puedes utilizar esta obra para fines comerciales.

Licenciamiento Recíproco - Si alteras, transformas o creas una obra a

partir de esta obra, solo podrás distribuir la obra resultante bajo una licencia

igual a ésta.

\section{Esto es un resumen fácilmente legible del: texto legal (de la licencia completa)}

En los casos que sea usada la presente obra, deben respetarse los términos especificados en esta licencia.
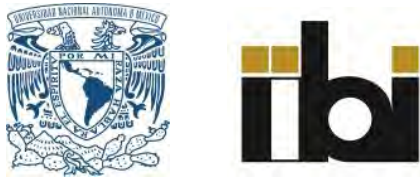
La mediación en el campo informativo documental 
EPISTEMOLOGÍA DE LA BIBLIOTECOLOGÍA Y ESTUDIOS DE LA INFORMACIÓN Instituto de Investigaciones Bibliotecológicas y de la Información 


\section{La mediación en el campo informativo documental}

Coordinador

Miguel Ángel Rendón Rojas

Universidad Nacional Autónoma de México 2017 
Z665 La mediación en el campo informativo documental / coor-

M43 dinador Miguel Ángel Rendón Rojas. -- México : UNAM, Instituto de Investigaciones Bibliotecológicas y de la Información, 2017.

$$
\begin{gathered}
\text { vii, } 97 \text { p. -- (Epistemología de la bibliotecología } \\
\text { y estudios de la información) }
\end{gathered}
$$

ISBN: 978-607-02-8994-1

Este libro es producto del Seminario de Epistemología de la Bibliotecología y Estudios de la Información.

1. Epistemología de la Bibliotecología 2. Bibliotecarios -Mediación -- Información -- Usuarios I. Rendón Rojas, Miguel Ángel, coordinador II. ser.

Diseño de portada: Mario Ocampo Chávez

Primera edición, 2017

D.R. (C) Universidad NaCional Autónoma de MÉxico

Ciudad Universitaria, 04510, México D.F.

Impreso y hecho en México

ISBN: 978-607-02-8994-1

Publicación dictaminada 


\section{Contenido}

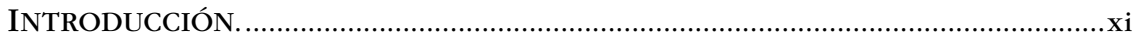

Miguel Ángel Rendón Rojas

LA MEDIACIÓN DE LA INFORMACIÓN:

DEL OBJETO AL DOCUMENTO

1

Cristina Dotta Ortega

DIMENSIONES DE LOS PROCESOS DE MEDIACIÓN

DEL CONOCIMIENTO. CONTRIBUCIÓN PARA UN DISCURSO

INTERDISCIPLINARIO EN CIENCIAS DE LA INFORMACIÓN.

Johann Pirela Morillo

Francys Delgado

MEDIAÇÃO E FILOSOFIA DA AUSÊNCIA: A INVENÇÃO

GRAMATICAL DA "MEDIAÇÃO HUMANA"

E SUPER-AÇÃO DO HUMANO.

Gustavo Silva Saldanha

LA MEDIACIÓN EN BIBLIOTECOLOGÍA/CIENCIA

DE LA INFORMACIÓN/DOCUMENTACIÓN.

ALGUNAS REFLEXIONES 81

Miguel Ángel Rendón Rojas 
A Cosette:

Quien me acompañó en el proceso de coordinación de este libro y siempre insistió en escribir algo en él. 


\section{Introduccion}

71 camino que hemos recorrido en nuestro análisis episteE mológico de la Bibliotecología/Ciencia de la Información/ Documentación nos ha llevado, al querer encontrar unos elementos mínimos en su fundamentación, entre otros conceptos, al de mediación. ${ }^{1}$ En efecto, independientemente de que la ciencia se llame Bibliotecología, Ciencia de la Información o Documentación; se privilegie una visión administrativa, ahora con el término menos 'burocrático' y más elegante de gestión, o una visión comunicacional; se parta de un enfoque sistémico holístico o de uno eminentemente pragmático-funcionalista; se tenga un compromiso social o un interés mercadológico; se conciba al objeto de estudio como actividad, proceso, institución, objeto, sujeto o algo complejo; en todos los casos siempre aparece la idea, la noción, aunque aún no la de concepto, de mediación.

Por consiguiente uno de los caminos, podemos decir casi naturales, para proseguir la indagación epistemológica del conoci-

1 El objeto de estudio de la bibliotecología/documentación/ciencia de la información. Propuestas, discusión, análisis y elementos comunes. (2013) Proyecto PAPIIT IN 401311. Miguel Ángel Rendón Rojas. Colaborador y coordinador. México: UNAM, Instituto de Investigaciones Bibliotecológicas y de la Información. pp. 287-295. 
miento sobre la realidad informativo documental, era el analizar dicha idea para tratar de aclarar su naturaleza, contenido, alcance y límites. Precisamente eso fue lo que hicimos, pusimos atención en la 'mediación'.

Ya desde 1998, cuando nos detuvimos en el análisis del profesional de la información documental, resaltamos el hecho de que no se le puede ver como a un simple mediador o intermediario entre los documentos y los usuarios, por lo menos no como un objeto del tipo de un dispensador de agua, comida, jabón o papel, un puente o un apagador; ni siquiera como otros objetos "inteligentes" como una computadora que funciona como servidor en una red, un smartphone, una Tablet, un ipad o un sofisticado software, ya que la función intermediadora no se reduce a un proceso meramente instrumental, mecanicista, técnico o tecnológico. ${ }^{2}$

De esta manera, presentamos los trabajos sobre esta temática.

En primer lugar encontramos el trabajo La mediación de la información: del objeto al documento. Dicho texto es una traducción, realizada por el autor de estas líneas, del original Mediação da informação: do objeto ao documento. Ya en el inicio del texto encontramos una primera aportación donde se distinguen los términos 'documental' y 'documentario'; el primero hace referencia al documento como tal, por lo que podemos usar ese adjetivo en frases como "acervo documental", "patrimonio documental", o los ejemplos que ella menciona: "soporte documental", "tipología documental”. Por su parte, el segundo término 'documentario' se refiere a los procesos que se realizan sobre el documento, con el documento y yo añadiría los que el profesional de la información documental lleva a cabo para cumplir su cometido como tal; es decir, cerrar ese ciclo de circulación del documento desde su creación hasta su uso para satisfacer las necesidades de información del usuario. De esta forma se emplea "descripción documen-

2 M. A. Rendón Rojas, "El papel del profesional de la información en el acceso y uso de la información" (1998), en La información en el inicio de la era electrónica. Información, sociedad y tecnología, vol. 2. México: UNAM/ CUIB, pp. 242-272. 
taria", "servicio documentario", "organización documentaria", o los ejemplos que en el texto se proporcionan, "análisis documentario" o "lenguaje documentario". Por fortuna, el Diccionario de la Lengua Española de la Real Academia Española ya reconoce el vocablo 'documentario-ria': "1. adj. Documental (II que se funda en documentos) U. m. en América". ${ }^{3}$ Por lo que no es necesario introducir un neologismo, aunque sí un significado distinto. Después de esta precisión, se indica que la mediación documentaria incluye un conjunto de acciones sobre los documentos que pueden ser tales desde el inicio de su creación por el autor, o se convierten en documentos gracias a esa acción mediadora del profesional de la información a través de actividades documentarias por medio de procedimientos especializados o, finalmente, se ven como documentos por un usuario final que abstrae información a partir de ellos. El objetivo del trabajo se centra en "[...] explorar la trasformación del objeto en un documento como resultado de las acciones de mediación" que finalmente son actividades documentarias que van desde la selección hasta la exposición. Para ello se analiza la noción de documento desde una perspectiva histórica aprovechando la visión lingüística y comunicacional aportada en particular por el enfoque francés que liga la mediación documentaria y lo que denomina dispositivos info-comunicacionales. De esta manera trata de lograr una síntesis entre las acciones de mediación de la información que se ven como actividades documentarias, el elemento procedimental técnico-científico propio del área, el aspecto comunicacional del proceso documentario y, como consecuencia de esto último, la importancia de la recepción (interpretación y uso) de los documentos por parte del usuario o, como ella lo llama, del público, para el que se realiza todo este proceso documentario.

En segundo lugar se presenta el capítulo Dimensiones de los procesos de mediación del conocimiento. Contribución para un

3 Cfr. Diccionario de la lengua española. Entrada "documentario". Real Academia Española. En línea: http://lema.rae.es/drae/?val=documentario (Fecha de consulta: septiembre 2015). 
discurso interdisciplinario en ciencias de la información. En este trabajo se hace énfasis en el aspecto cognitivo, por lo que se concibe la mediación como una mediación del conocimiento. La definen como la "[...] interposición y ubicación en medio de dos mundos o dos cosas con objeto de promover acciones que redunden en ganancia cognitiva e incremento del acervo de experiencias y de prácticas"; y a la mediación del conocimiento como un proceso por el cual se generan acciones-procedimientos de intervención entre la producción de mensajes y contenidos, por un lado, y su recepción por parte de usuarios por otro; lo que conlleva a que los sujetos emisores y receptores intercambien saberes, experiencias y a través de ciertas competencias se apropien de la información, le añadan valor, nuevos significados, y se desarrollen nuevos conocimientos. Como soporte teórico del análisis se emplea un sistema teórico que incluye conceptos por medio de los cuales se interpretan los procesos de mediación en las llamadas organizaciones de conocimiento (bibliotecas, archivos, centros de información y documentación) de la llamada cyber-sociedad. Dentro de ese sistema se encuentran macro-, meso- y micro-componentes. El análisis se realiza a través de cuatro dimensiones: ontológica, educacional, comunicacional e informacional. Como resultado de ese análisis multidireccional, la mediación del conocimiento se descubre como un proceso transversal que atraviesa diferentes esferas de la acción humana y social. Finalmente llegan a la conclusión de que para fundamentar de manera unificada a las ciencias de la información utilizando como conceptos guía los procesos de mediación y la construcción de conocimiento, es necesario partir de un enfoque interdisciplinario y tomar en cuenta esos procesos, no sólo desde una perspectiva informacional, sino también educacional así como comunicacional. La riqueza teórica y metodológica de esos procesos -mediación y construcción del conocimiento- permite también, según los autores, comprender la naturaleza y alcance de las organizaciones de conocimiento y de los profesionales que las dirigen.

Finalmente, tenemos el trabajo Mediação e filosofia da ausência: a invenção gramatical da "mediação bumana" e super-ação 
do bumano (La mediación y la filosofía de la ausencia: la invención gramatical de "mediación humana" y de la super-acción del humano). En el texto se analizan las relaciones entre el lenguaje, la mediación y la técnica a partir de la filosofía del lenguaje. A lo largo del trabajo, el autor trata de mostrar cómo la separación producida por argumentos representacionistas sobre el lenguaje provoca la aparición de dicotomías, como fuera y dentro, humano y técnica, cultural y tecnológico, que alejan la comprensión epistemológicohistórica de la noción de "mediación" entre Filosofía y Ciencia de la Información. Como consecuencia de esa ruptura se llega al límite de una confrontación entre una filosofía de la presencia y una filosofía de la ausencia en los estudios informacionales. El autor utiliza la hermenéutica epistemológico-informacional propuesta por Rafael Capurro, como marco teorético y metodológico que dirige y justifica su disertación sobre la construcción de las "cosas" a partir del lenguaje, así como las consecuencias que esto conlleva para la elaboración del concepto de mediación en el campo de la Ciencia de la Información. Aprovecha las propuestas de Jacques Derrida y Sylvain Auroux, matizadas con ideas de Barbara Cassin y de Ludwig Wittgenstein sobre la producción gramatical de la realidad simbólica, propiciada en nuestra episteme por la escritura, para analizar las dicotomías mencionadas. A partir de la comprensión de la constitución gramatical (técnica) de la noción de "mediación humana", el argumento general gira en torno a la noción de acción, de pragmática, como lo central de las prácticas de mediación.

La comprensión de este concepto de mediación es esencial para construir una epistemología de la Bibliotecología/Ciencia de la Información/Documentación como ciencia general o desde otra perspectiva de la Archivística, Bibliotecología, Biblioteconomía, Ciencia de la Información, Documentación y Museología como disciplinas informativo-documentales particulares. Así pues, invitamos a leer in extenso los trabajos de este libro y a que la información que de ahí se obtenga sea material para construir un nuevo conocimiento. 


\title{
La mediación de la información: del objeto al documento ${ }^{1}$
}

\author{
Cristina DotTA ORTEgA \\ Universidad Federal de Minas Gerais, Brasil
}

\section{INTRODUCCIÓN}

T a mediación de la información, o la mediación documentaria, engloba el conjunto de las acciones realizadas sobre los objetos, desde la perspectiva de las personas en torno a actividades comunes -científicas, profesionales, estéticas, recreativas- lo que conlleva a que esas personas sean tomadas como público y los objetos sean nominados como documentos.

La mediación de la información implica intervención, acción propositiva, intencionalidad, y su objetivo es la apropiación de la información. Se realiza sobre una base material por medio de metodologías con rigor científico. La identificación, selección, registro, ordenación, preservación, exposición de todo y de cualquier objeto son actividades documentarias en el sentido de que constituyen -de modo articulado entre sí- acciones de mediación a partir de las cuales se produce una transformación del objeto en documento. Estas acciones forman capas de significado sobre el objeto, cada una de las cuales resignifica a la anterior, en un movimiento de

1 Traducción del original en portugués Mediação da informação: do objeto ao documento por Miguel Ángel Rendón Rojas. 
producción de mensajes para un público. El documento es ese objeto resignificado y su noción de documento depende de una elaboración teórico-metodológica de estas acciones.

Este trabajo tiene como objetivo explorar la transformación del objeto en un documento que es el resultado de las acciones de mediación de la información.

Entre los problemas que nutrieron el trabajo, se tiene el problema de los criterios adoptados para elegir los objetos como documentos, ya que las prácticas profesionales y los programas de enseñanza han creado mentalidades en torno a ciertos objetos y no a otros; pero al mismo tiempo se relegan diversos documentos, como: documentos electrónicos, bienes inmuebles, textos escritos inéditos, documentos audiovisuales e informaciones catastrales y estadísticas (como las relativas a los eventos y actividades de grupos e individuos). El problema puede observarse en el tardío uso del término documento, ya sea por el apego al término información que llevó a la infravaloración de la base material y fijarse solamente en el contenido, ya sea por la fuerza ideológica y económica del enfoque técnico-normativo de la comunidad anglo-estadounidense de bibliotecas, fuertemente orientadas a trabajar con libros en soporte de papel.

En este contexto se adoptó el término "mediación" que intenta proporcionar mayor relevancia a las prácticas profesionales bibliotecarias, por ejemplo en los servicios de referencia, u otras acciones en las que se da una relación directa con el público. El término mediación de la información, considerado de forma aislada respecto a otras acciones realizadas, se usa más como una etiqueta para reunir esas acciones que como un modo de significarlas. La ausencia de un significado preciso del término contribuyó a relegarlo a la idea de puente para el acceso a los documentos por los usuarios o mera acción facilitadora del proceso. También la literatura y la práctica museológica han privilegiado la exposición como acción de mediación en detrimento de otras acciones que la preceden, así como las posibilidades de mediación que prescinden de la experiencia de una exposición, como es el caso con la investigación de la colección por especialistas o con la visita a la reserva técnica por diversos públicos. 
De este modo los problemas identificados se refieren a la visión desarticulada de las acciones de mediación, siendo consideradas como tal aquellas en las que se da una relación directa con el público; mientras que las otras acciones se ven como operaciones mecánicas realizadas por medio de orientaciones normativas predeterminadas. Asimismo también se trata, en especial en Biblioteconomía, de la simplificación de la noción de mediación y de la naturalización del proceso de identificación de documentos.

El trabajo se justifica por la necesidad de evidenciar la función de las acciones de mediación en cuanto procedimientos especializados, sin los cuales las posibilidades de comunicación se restringen o dependen de factores arbitrarios ajenos a esas acciones, por lo que también son contingentes y eventuales. Al mismo tiempo dichos procedimientos son medios para lograr ciertos objetivos, motivo por lo cual es preciso establecer la relación entre éstos y aquéllos. Ese proceso depende del objetivo que se persigue, lo que lleva a identificar la contradicción que enunciamos de la siguiente manera: ¿cómo procedimientos supuestamente no interpretativos permiten lograr un objetivo de la dimensión de lo simbólico?

Como metodología, se analiza la noción de documento, incluyendo algunos aspectos de su constitución histórica; se conciben las actividades documentarias como acciones de mediación de la información, por lo tanto intencionales, que se explican como un proceso lingüístico donde juega un papel determinante la recepción del documento; se exploran algunas actividades documentarias, desde la identificación y selección hasta los servicios de difusión y de exposición, utilizando la literatura científica existente en materia bibliográfica y museológica, y estableciendo las relaciones entre ellas; y, por último, se presenta el enfoque francés desarrollado alrededor de los términos de mediación documentaria y de dispositivos infocomunicacionales, que es heredero del concepto de documento y del enfoque lingüístico y comunicacional tratados inicialmente. 


\section{LA NOCIÓN DE DOCUMENTO}

La noción de documento se discutió y elaboró durante el siglo XX, de la siguiente manera (Ortega y Lara, 2010):

El nombre del área propuesta por Otlet, -Documentación- derivado de su objeto -documento-, implica ideas, acciones y productos que configuran temas que hoy son estudiados por su actualidad y pertinencia. Otlet hace mención de un soporte de una cierta materia y dimensión (...) en la que se incluyen signos representativos de ciertos datos intelectuales (...) y elementos constitutivos materiales, lingüísticos, gráficos e intelectuales (Otlet, 2007, p. 43). Sagredo Fernández e Izquierdo Arroyo (1983, p. 309) afirman que la Documentología (como es usada por Otlet) trata de la atribución hermenéutica (o interpretativa) en el sentido de buscar medios y métodos que den cuenta del mensaje del autor. El documento se explica a partir de su propia producción, o de la producción documentaria, según Briet (1951). El Traité de Documentación de Paul Otlet (1934), y el libro Qu'est-ce que la documentation? de Suzanne Briet (1951), contribuyen a entender que los términos "documento" y "documentación" ya tenían en germen la noción de información tal como se entiende hoy en día.

En el contexto de los estudios del grupo francés formalizado en la década de 1970 en torno a las Ciencias de la Información y Comunicación, Escarpit (1991), en un libro publicado inicialmente en 1976 y Meyriat (1981), añaden que el uso es lo que 'hace' el documento e introducen las nociones de comunicación, significado y la palabra "información" con sus derivados. Meyriat (1981: 51) afirma que el documento se puede definir como un objeto que le da soporte a la información, sirve para comunicar y es durable. Para él, la definición de documento opera a través de dos conceptos inseparables el uno del otro, ya que su conjunción es esencial: una naturaleza material (el objeto que sirve de soporte), y otra conceptual (el contenido de la comunicación; es decir, la información).

La literatura española del mismo periodo demuestra ser tributaria de la construcción francesa del término documento, así como del enfoque peculiar que tienen de Documentación, entre otros, 
enfatizar su relación con la producción científica. De esta manera podemos decir que la noción de documento propuesta por los primeros documentalistas (Otlet y Briet) fue profundizada y actualizada por los investigadores franceses y españoles en las siguientes décadas.

En cuanto a los aportes a la noción de documento en lengua inglesa, dos autores contemporáneos (Buckland y Frohmann) discuten sobre el documento tomando como base a los documentalistas Otlet y Briet. No citan a los investigadores franceses y españoles discípulos de esos primeros documentalistas, sino que reiteran sus ideas, como la de que ningún objeto por sí mismo podría ser definido como documento. Buckland (1991: 352) propone invertir la pregunta de siempre "¿qué es informativo?" preguntándoles a las personas qué cosas identifican que les permiten convertirse en informadas. Frohmann (2004) se refiere a la informatividad como el conjunto de factores que deben tenerse en cuenta para entender cómo los documentos se convierten en informativos (diríamos: cómo los objetos se convierten en documentos por ser abordados informativamente).

Como hemos visto, en relación a la pregunta de qué es un documento, la caracterización física o tipológica no se muestra productiva. La noción de documento depende de un cierto modo de percepción de un objeto, el cual cambia a medida que le son aplicadas en un movimiento continuo unas acciones de atribución de significado. El documento es el producto de las actividades sistémicamente realizadas con el propósito de apropiarse de información por un público. En otras palabras, los documentos son informaciones seleccionadas y organizadas materialmente en un sistema cuyos significados objetivan, y a su vez, orientan el proceso de significación para el público.

En cuanto a los dos elementos que lo constituyen -materiales y simbólicos- el documento debe ser abordado en su plasticidad, lo que conlleva a identificar los siguientes productos en forma de objetos y referencias/registros de los mismos, de la siguiente manera: los documentos, serán tomados como objetos; así mismo, los registros que representan estos documentos en su totalidad, en su conjunto, o en sus partes; registros (catastrales, estadísticos) ela- 
borados a partir de varios documentos; y registros construidos a partir de transacciones (es decir, operaciones administrativas). Conceptos comunes a las perspectivas archivística, museológica y bibliográfica son el resultado de los esfuerzos de fundamentar las acciones sobre los objetos frente a un púbico. Por lo tanto, es necesario aclarar los aspectos esenciales del camino que va del objeto al documento, distinguiéndolos de los aspectos contingentes de las prácticas institucionales que a su vez se plasmaron en la literatura técnica, pero no son suficientes para construir una noción de documento que responde a la mediación de la información, posibilitando un mayor acercamiento a una epistemología del área.

Tomando como base a Meyriat (1981) y contemporáneos, el documento es: el objeto producido con la intención o no de ser el documento (producción de documento); y el objeto que puede funcionar como documento, pues su uso como tal es lo que determina que lo sea (uso del documento). Además de eso, es necesario considerar que la función de la información del documento puede cambiar (uso del documento en el tiempo). De este modo, un documento elaborado con esta intención no es definitivo para una situación de "ser documento" pues eso depende de que él mismo sea tomado como tal, aunque los enfoques iniciales sean reformulados al transcurrir el tiempo.

De modo similar, Buckland (1991, 355) propone el 'discurso' como un término mejor para indicar textos o artefactos considerados en cuanto a la intención de representar cosas. Presenta la posibilidad de dividir los objetos tomados como discursivos en: artefactos elaborados con la intención de constituir un discurso (como los libros), artefactos que no tenían esa intención (como barcos), y objetos que no son artefactos (como antílopes). Ejemplifica la variación de la función del objeto en el tiempo, citando el libro, que puede ser utilizado como un soporte para las puertas.

Meneses corrobora las ideas de Meyriat y Buckland, ya que de acuerdo con este autor brasileño (Meneses, 1994, p. 21), los documentos de origen, típicos de las sociedades complejas, son aquellos diseñados para registrar información. Sin embargo, en tanto cualquier objeto puede funcionar como documento, el mismo do- 
cumento de origen puede proporcionar informaciones jamás previstas en su programación. Meneses observa que el documento siempre se define en relación a un tercero, el cual es externo a su contexto original, y que toda la operación con los documentos, es por tanto, de naturaleza retórica.

De esta manera, autores como Buckland y Meneses refuerzan la noción de documento de Meyriat publicada en 1981. Posteriormente, según Couzinet, Régimbeau y Courbières (2001), en 1995 Fondin desarrolla el concepto y actualmente se encuentra incorporado a la producción francesa de conocimiento sobre los términos 'documento por intención' y 'documento por atribución'. Para precisar el término "documento por intención”, el propio Meyriat retoma la cuestión y la esclarece. Para él (2006: 12), como todo producto de la actividad humana, el documento aparece en el lugar (inmaterial) y en el momento en el que se reencuentran los diversos sistemas sociales o técnico-sociales de los que es derivado. El documento por intención es solamente aquel especialmente producido para vehicular la información, de tal modo que, si el autor produce un libro o un artículo, el 'documentalista' legitima ese libro o artículo como documento, insertándolo en los procesos de circulación, por medio de actividades que se articulan con las de otros grupos, como los editores y libreros. Meyriat explica que el documento por intención es producto de por lo menos dos sistemas, el que produce el objeto y el que emite la información inscrita sobre ese objeto, llamando la atención sobre el riesgo de ambigüedad en la comprensión de este término. (Meyriat, 2006: 13) Por último, sintetiza su análisis del documento por intención de la siguiente manera: el documento no es un simple vehículo de información, más bien interactúa con la misma, ya que le es consubstancial, es decir, es su elemento constituyente. El documento tiene un autor que no puede ser ignorado y que tiene una intención de comunicar, lo que se traduce en el objetivo atribuido al documento; este autor es un ser social que ejerce muchos papeles y que pueden cada uno imponerle diferentes limitaciones; y todo documento se inscribe en un sistema específico de comunicación que busca un objetivo propio. (Meyriat, 2006: 26) Como vemos, la 
síntesis es de tal forma tan abarcadora que podríamos incluir en ella todo y a cualquier documento, desde que la figura del autor fuera sustituida por el conjunto de individuos, incluyendo documentalistas que actúan sobre los objetos haciéndolos documentos.

Podemos afirmar que el documento por intención es una denotación permanente en relación con el objeto al que se refiere, ya que esa relación denotativa es una característica intrínseca a su producción. Es más, podemos decir que la información es más evidente en el documento por intención, como es el caso de los textos científicos escritos que se inscriben en los flujos de comunicación científica. Al considerar el documento como un objeto que significa, podemos hablar de al menos tres niveles de significación: la producción de documentos con intención informativa; las propuestas de significado sobre esos documentos para un público; y el significado que se produce en el proceso de apropiación de la información realizado por el usuario. El segundo nivel de significación es responsabilidad del profesional documentalista y de otros que actúan material y simbólicamente sobre el documento, y el tercer nivel es el objetivo y la motivación de los anteriores. No obstante, si las actividades documentarias son acciones de mediación realizadas con intención informativa sobre objetos, esos mismos objetos pueden o no ser producidos con intención informativa. Para que sea propiamente un documento, el objeto debe de ser utilizado como tal (documento por atribución) y no solamente propuesto como tal (documento por intención), a pesar de que los dos casos involucran procesos interpretativos. De este modo, aunque el primer nivel de significación no es obligatorio, ni el segundo deba de existir necesariamente, sí es preciso el nivel de significación realizado por el usuario para que exista el documento, y por consecuencia, su definición.

Sin embargo, considerando el papel fundamental desempeñado por la mediación, principalmente en las sociedades que se han vuelto más complejas por el conocimiento y la tecnología, es necesario explorar las contribuciones teóricas y metodológicas sobre los niveles de significación de la producción y recepción del documento. 


\section{EL DOCUMENTO EN RELACIÓN}

\section{CON EL LENGUAJE Y CON LA RECEPCIÓN}

Para García Gutiérrez (1999: 24-25, 33), la Documentación es una disciplina social cuyo objetivo principal es estudiar los razonamientos introducidos en los documentos para poder extraer modelos de comprensión, análisis y organización. Por lo tanto, según este autor, esta disciplina se encuentra ligada (mas no dependiente) a la tecnología, y se construye a través de un proceso lingüístico e informativo. García Gutiérrez afirma (1999, 34 y 35) que JeanClaude Gardin introdujo el enfoque lingüístico cuando analizó la estructuración del conocimiento, los métodos de lectura de texto y la elaboración de lenguajes de simbolización para este propósito.

El pensamiento gardiniano, propuesto desde la década de 1960, es reconocido como uno de los más fructíferos de la investigación sobre organización de la información, y el cual facilitó estudios posteriores muy importantes para la consolidación científica del área. En este sentido, junto con los modelos de comprensión de textos y de lenguajes documentarios adoptados para ellos, actualmente se trabajan métodos de representación documentaria vinculados al universo lingüístico de los usuarios, lo que implica estudiar también la actividad realizada por el grupo social en cuestión y los aspectos culturales relacionados con dicho grupo. Sin embargo, según García Gutiérrez se produjo un debilitamiento del enfoque lingüístico propuesto por Gardin, ampliamente adoptado hasta la década de 1980, que llevaron al área a una "reducción monástica medieval", lo que contribuyó a disminuir su influencia sobre políticas y prioridades científicas (García Gutiérrez, 1999: 25)

A pesar de que en periodos anteriores había un número mayor, los estudios del lenguaje aplicados a la Documentación se mantienen, en especial aquellos que versan sobre los fundamentos del lenguaje documentario (como el tesauro) y las metodologías para su construcción con las aportaciones de la Terminología. La teorización sobre el lenguaje documentario muestra mayor desarrollo en torno a cuestiones de su base conceptual y metodológica en comparación con los procesos de descripción formal de documentos y sus instru- 
mentos, los cuales son abordados preferentemente de modo prescriptivo. Aunque marcadas por diferentes etapas de fundamentación científica, entendemos que la totalidad de las actividades documentarias tiene lugar a través del lenguaje, cada una de acuerdo con sus especificidades.

Como afirmamos en Lara y Ortega: “[...] el enfoque lingüísticosemiótico permite proponer el documento como un signo, un objeto que tiene forma y contenido (Hjelmslev, 1975), que representa algo para alguien, sobre un aspecto o capacidad" (Peirce, 1977). Lara y Ortega (2012: 381).

Como signo, el documento es una construcción, una lectura de lo "real" sobre determinada perspectiva. La "lectura" del objeto que lo convierte en documento para el sistema sigue una política de información que favorece las perspectivas institucionales y las comunidades discursivas potenciales. El documento se vuelve pertinente a partir de la selección, descripción formal y atribución de descriptores u otras unidades de clasificación e indización, en cuanto actividades de organización de información que son seguidas por otras actividades documentarias. Las actividades documentarias son el resultado de una serie de elecciones, pues los documentos son organizados en categorías por medio de aspectos que se priorizan frente a otros, lo que implica una construcción que está permeada de elementos ideológicos (Lara y Ortega, 2012: 381-382).

Las reflexiones francesa y española sobre el documento, presentadas en la sección anterior, destacan la recepción del documento. Al considerar el proceso de comunicación, se deduce que el documento es un producto de una relación que implica emisor, interlocutor y contexto. Un objeto es un documento en cuanto es considerado el mapa de configuraciones a partir de las cuales puede tomar forma y llegar a tener sentido para alguien (Lara y Ortega, 2012: 385).

Al mismo tiempo, otra cuestión a considerar es la relación entre la intencionalidad que define la actividad documentaria y la ausencia de control sobre la interpretación del público. 
El punto es que la recepción del documento origina una negociación de sentido, lo que convierte en vacía la suposición de que existe una correspondencia biunívoca entre lo que se dice y su interpretación (Lara y Ortega, 2012: 384). Según Lara (2007: 159), no considerar la intencionalidad significaría, o suponer la posibilidad de neutralidad de las actividades documentarias, o no considerar las especificidades de esas actividades al ampliar el espectro del trabajo con la información a todo y a cualquier campo de conocimiento o actividad.

Por lo que corresponde a las visiones anteriores mencionadas, esa posición también es asumida por Meneses para quien reducir la colección a un

[...] almacén de significantes disponibles para los significados elegidos en self-services por los usuarios, sin ninguna mediación, sin presuponer procesos cognitivos e incluso fuerzas que actúan en el interior de la sociedad capitalista en que vivimos es "tirar al niño junto con el agua del baño" (Meneses, 1994: 13).

Meneses (1994: 23) considera; sin embargo, que esto no equivale a suponer que una exposición sólo será fructífera con la mediación de un monitor, puesto que hay cuestiones metodológicas en las acciones llevadas a cabo en los museos. Para Meneses (1994: 24), la principal consecuencia de no tener un trabajo de mediación es el debilitamiento de la dimensión política del museo, a menudo reemplazado por el paternalismo. En otras palabras,

[...] la alienación, la marginación y la dependencia son el precio de la ausencia o la restricción de mediaciones documentarias (organizadas), en una sociedad precisamente tan mediada como la nuestra, y tan jerarquizada por la información (Meneses, 1994: 64).

Kobashi y Tálamo (2003: 20) presentan una problemática semejante al tratar investigaciones propuestas sobre bibliotecas y otras instituciones similares. Las autoras cuestionan los repetidos estudios de usuarios basados en un recorte social preexistente (como 
la situación profesional, económica, educación, etc.), en lugar de ser contemplados los modos por los cuales se puede acceder al contenido, administrarlo y comprenderlo.

Reconocer el lenguaje como elemento de la cultura y actuar de manera efectiva con él en el ámbito de las actividades documentarias proporcionan, según Lara, la

[...] posibilidad de ejercer más convenientemente el papel de mediador al movilizar tanto referencias de enunciación (a través de unidades terminológicas tejidas en los discursos de especialidad) como de recepción (los usos de la comunidad de usuarios socialmente constituida). Desde esta óptica se contempla mejor al usuario como el tema de la interpretación (2007: 155).

La mediación significa algo que está entre una cosa y otra cosa -en este caso, las personas y los objetos- sin que pueda faltar alguna de ellas para que el concepto se realice. El énfasis en el usuario y en los aspectos sociales y culturales hace necesario explorar el problema de la segmentación entre los estudios de organización de la información y el estudio de usuarios. Por un lado, tenemos estudios de organización de la información que no consideran al público al que se destinan (aunque existen propuestas importantes en este sentido como ya mencionamos), y por otro lado tenemos estudios de usuarios que no se relacionan con una propuesta de significado que se les ofrezca a través de acciones de mediación.

Ante la falta de producción de mensajes basados en la identificación del lenguaje del público-objetivo y del lenguaje de los documentos, la mediación depende del conocimiento del sujeto (sobre los documentos y el mundo que los rodea) quien dialoga directamente con el público. Esta situación no se caracteriza como mediación estrictamente documentaria -mediación entre la producción material trabajada en cuanto sus posibles significados para un grupo- pues las diversas acciones de producción de significados que la constituyen no son realizadas o no son tomadas en cuenta. De esta manera se debe observar cuál es el tipo de mediación en 
juego, ya que podríamos hablar de mediación cultural, mediación de lectura o mediación tecnológica. La necesaria consideración de estos aspectos para la mediación en cuestión no permite que ésta sea nombrada de un modo u otro, sin correr el riesgo de oscurecer su singularidad.

\section{ACTIVIDADES DOCUMENTARIAS: \\ DE LA SELECCIÓN A LA EXPOSICIÓN}

Como hemos dicho, la mediación de la información se lleva a cabo por medio de actividades documentarias; es decir, actividades en documentos teniendo presente a un público, como: identificación, selección, producción de registros, ordenación, conservación, servicios de difusión y exposición.

La identificación involucra una cuestión abordada en el primer apartado; a saber, la discusión sobre si el objeto es un documento. De la pobre discriminación de Otlet al afirmar que todo puede ser documento, a la determinación del soporte y la tipología documentales recurrentes en la literatura sobre las bibliotecas, pasamos a considerar la perspectiva del lugar que ocupan los documentos como una manera de identificarlos como tales. Este lugar (simbólico) imprime una función que se adopta para su caracterización como un documento.

El proceso iniciado con la identificación permite la selección, que tiene en la colección el primer producto documentario. Dos conceptos básicos deben ser considerados: la colección de los documentos y las referencias de los documentos (Ortega, 2011: 196-198). La colección es el conjunto de documentos seleccionados que se relacionan entre sí, llegando a ser algo coherente y con personalidad propia. Las referencias son registros (de bases de datos) que ofrecen la oportunidad de tener acceso a esos documentos de los que se informó su existencia; o registros (catastrales, por ejemplo) que proporcionan ellos mismos la información de interés. A partir de la relación entre la colección y las referencias/registros es posible explorar la diversidad de los sistemas de información; se pueden indicar aquellos que 
presentan una colección de documentos ordenados y una base de datos que las referencie; una colección de documentos ordenados en ausencia de una base de datos; y una base de datos en ausencia de documentos ordenados. En este último caso tenemos bases de datos cuyos registros referencian documentos electrónicos o lo que Buckland llamó (1991: 354) colección virtual de documentos, refiriéndose a personas, edificios u otros objetos que, en cualquier situación, no podrían ser recolectados y almacenados (aunque sus referencias podrían ser organizadas).

La colección no depende de la transferencia física de los documentos. De ello se desprende que la colección no pueda ser identificada con el conjunto de objetos almacenados en el mismo local, pues ella es el conjunto resultante de opciones percibidas por la disposición espacial de los documentos y/o por sus referencias organizadas en bases de datos.

Meneses (1994: 12), de manera convergente, discute el tema que llama "museo sin acervo" por medio de los términos 'acervo notarial' y 'acervo operacional'. El acervo notarial consiste solamente en lo que es posesión institucional del museo, mientras que el acervo operacional está constituido por todo tipo de evidencias en cualquier lugar. Según el autor, el acervo notarial depende de la colección, pero es sobre el acervo operacional sobre el que se realiza el trabajo museístico, ya que "[...] el acervo es una presuposición porque el problema en cuestión es el conocimiento. Es, en última instancia, a causa del conocimiento, que los acervos institucionalizadas se hacen insustituibles" (Meneses 1994: 62). Para Meneses el problema gira en torno a la cultura material con la que el área tiene que lidiar, porque esa coincidencia conduce, para cualquier tipo de museo, a que el acervo jamás pueda limitarse a las colecciones depositadas y registradas intramuros. En cuanto a la relación que hemos mencionado entre la colección y las referencias, este autor afirma que "[...] es urgente ampliar la noción de acervo cartorial a la de acervo operacional, completados ambos necesariamente con bases de datos, naturalmente informatizados". (Meneses 1994: 62)

La colección virtual de Buckland y el acervo operacional de Meneses permiten repensar el museo y la biblioteca (entre pare- 
des) al constatar que éstos no son definidores de acciones de mediación de información. Un proyecto institucional, empero; está siempre en cuestionamiento, pues por medio de él es como las acciones concretas de la mediación son claramente identificadas.

La producción de bases de datos informatizadas a las que se refiere Meneses es denominada usualmente 'documentación' en la práctica museística (a pesar del significado más amplio que tiene el término documentación como un conjunto de actividades documentarias). El dossier de la revista Documentaliste sobre el tema Documento y Museo trata de estas prácticas profesionales, tratando de demostrar que las mismas pueden ser consideradas como un pivote entre la organización interna del museo y la misión de mediación (Rizza, 2014: 28). Cada artículo de la revista refuerza la función de producción de referencias o de registros sobre los objetos como parte de las acciones de mediación. Després-Lonnet (2014: 61) afirma que los textos producidos sobre objetos a partir de la documentación están cada vez más presentes en las salas de exposición y en las páginas web de los museos. Para ella "[...] desde un punto de vista info-comunicacional, la exposición así como el catálogo pueden ser estudiados como dispositivos enunciativos y discursivos" (Després-Lonnet 2014: 61), una vez que

[...] los textos producidos en cada ámbito responden a exigencias diferentes, pero la documentación es siempre central para la construcción de dispositivos de mediación. Ella es la base material e intelectual a partir de la cual la exposición será conocida en un espacio y un discurso (Després-Lonnet, 2014: 62).

Del mismo modo, Régimbeau (2014: 44) afirma que la transversalidad de las funciones de la información y comunicación en los museos, supone una concepción de la práctica documentaria en la que cada intervención desencadena una necesidad, asociando técnica y mediación.

Por último, tenemos las actividades documentarias que se centran con mayor fuerza en los objetos y el espacio en el que están dispuestos -la ordenación o la disposición de documentos- como el 
modo de lectura de la colección y el recurso de acceso a los documentos y a la exposición. Estas actividades ocurren en las siguientes situaciones (a excepción de la perspectiva archivística): la ordenación de documentos de acervos (en perspectiva bibliográfica) y la ordenación de documentos de la reserva técnica (perspectiva museológica), y las exposiciones a partir de colecciones producidas en una perspectiva bibliográfica o museológica.

En el caso de la exposición existe una diferencia en cuanto a otras actividades documentarias, que se da por la relación entre lo cognitivo (aprehensión informacional del objeto) y lo sensorial (aprehensión sensible del objeto).

A pesar del papel del escrito, Otlet, cuando trata cuestiones sobre el museo a principios del siglo XX, entiende que por medio de la visualización es posible la adquisición de conocimiento, a su vez, tal visualización se configura como una ampliación de la concepción del acto de conocer (Mendes, 2013: 196). Por su parte Meneses refuerza la idea de entender que la visualización

[...] es más eficiente que la escritura y otros sistemas intermediados de registro ya que la matriz sensorial facilita el recuerdo. A partir de la selección mental, ordenamiento, registro, interpretación y síntesis cognitiva en la presentación visual, se gana notable impacto pedagógico (Meneses, 1994: 9-10).

Según Meneses (1994: 37), se trata de un discurso que presupone la articulación de enunciados sobre ciertos problemas humanos, desarrollados con el soporte de las cosas materiales. Simultáneamente este autor define la especificidad del lenguaje museológico como esencialmente espacial y visual, y no como una simple variación o adaptación del lenguaje verbal (Meneses, 1994: 38). Aunque considerando la producción de textos sobre los objetos, Meneses entiende que en la exposición algo es "dicho" con los objetos, que no es responsabilidad de subtítulos y otros recursos como audiovisuales o electrónicos.

Sin embargo, el objeto no debe ser presentado en una exposición como representante de un hecho, sino indicando su relación 
con un cierto modo de comprensión o enfoque de un hecho. Es importante la concepción de museo que tiene Otlet de que "[...] al considerar que el mundo no está hecho de artefactos, sino de hechos o ideas, daba importancia no al objeto en sí, sino a su significado, a lo que él representaba en función de las ideas que lo produjeron" (Mendes, 2013: 196).

Meneses (1994: 27) resalta que los objetos materiales sólo disponen de propiedades materiales (de naturaleza físico-química), siendo todos los demás atributos, como los sentidos y los valores (cognitivos, afectivos, estéticos y pragmáticos), no de las cosas- sino de la sociedad que los produce, almacena, hace circular, consume y recicla y descarta, aunque movilizando algún atributo físico.

Tratando de explorar la relación entre lo cognitivo (aprehensión informacional del objeto) y lo sensorial (aprehensión sensible del objeto), es necesario recordar que la producción de referencias, preferiblemente en forma de registros de base de datos, puede contribuir a la exposición, sin perjuicio de la propuesta sensorial en juego. Continuando con las actividades de identificación, selección, producción de registros y ordenación, la exposición sintetiza otro nivel más de significado del objeto en cuanto documento. A su vez, el trabajo informacional permite la gestión del documento en el nivel administrativo (adquisición, préstamo, etc.) y el de contenido (representación).

El término musealización es indicativo de las acciones diversas y articuladas de las que hablamos. A partir de Desvallés y Mairesse (2013: 57) entendemos que la musealización es el proceso científico que comprende del conjunto de actividades de selección, conservación, catalogación, exposición, publicaciones, etc. De este modo, encontramos dos posiciones de la perspectiva museológica que corroboran nuestra propuesta sobre la mediación. Meneses (1994: 30-31) habla del museo como una forma institucionalizada de transformar objetos en documentos mediante el recurso de "la confrontación del objeto". Para este autor el museo se compromete en su potencial a desvincularse de las obligaciones científico- 
documentales (Meneses, 1994: 41). Para Lara Filho (2009: 163), las acciones de mediación son realizadas por la

[...] búsqueda de sentido, ofreciendo la posibilidad de, a partir de correlaciones que se establecen en la construcción de la información, presentar el objeto en sus diferentes contextos y sugerir posibilidades de apropiación y de participación efectiva de los públicos (Lara Filho, 2009: 163).

\section{HACIA UNA MEDIACIÓN PROPIAMENTE DOCUMENTARIA}

Si en Brasil se habla de mediación en Ciencia de la Información o de mediación de la información, manifestamos especial interés por el término francés médiation documentaire en función de sus orígenes vinculados al concepto de documento construido en torno a la idea de soporte y de interpretación sobre él mismo, o que es producto de la mediación, como tratamos anteriormente. En este enfoque, a partir del significado y la comunicación, los elementos lingüísticos son vistos como un modo de operar las actividades documentarias que realiza la mediación.

La producción científica a la que nos referimos se hace explícita en las actividades del grupo de investigación coordinado por Viviane Couzinet, Médiations en information-communication spécialisée (MICS), del Laboratoire d'Etudes et de Recherche Appliquées en Sciences Sociales Aplicadas (LERASS) de la Universidad de Toulouse 3 - Paul Sabatier. El grupo se creó en 1995 y se inscribe en la relación que une a la información y la comunicación en el desarrollo de los trabajos de los fundadores de las Ciencias de la Información y Comunicación, a los que nos hemos referido anteriormente. Desde 2007, el grupo creó una red internacional con investigadores brasileños llamada red MUSSI. El proyecto del equipo se guía por la observación y la comprensión de la complejidad de las interacciones que conducen a las mediaciones que toman forma en los dispositivos info-comunicacionales híbridos y por la elaboración de conceptos que les proporcionan precisión a los modos de aproximación realizados. 
Los dos ejes trabajados por el grupo incluyen: el análisis de la mediación documentaria en el contexto de la definición de documentología como ciencia del documento y documentografia como método que, observando en una dimensión socio-histórico de los objetos que estudia, elabora una clasificación filogenética documentaria; así como el análisis de la mediación, de la cultura y de la ciencia, observando lugares, discursos y dispositivos.

La expresión 'mediación documentaria' fue adoptada como objeto de investigación, en particular por Isabelle Fabre, así como por Cécile Gardies, ambas miembros del grupo de investigación citado. El término 'mediación' se adoptó en el enfoque documentario desde la década de 1980, pero varios trabajos fueron publicados recientemente, como los que siguen (en orden cronológico): Couzinet (2000), Régimbeau (2007), Fabre Veyrac (2008), Jeanneret (2008), Couzinet (coord.) (2009), Liquete, Fabre y Gardies (2010), Régimbeau (2010), Fabre y Gardies (2010), Fabre (2012), Gardies y Fabre (2012) y Fabre (2013).

Entre las obras anteriores, nos es de especial interés la de Fabre y Gardies (2010), para quienes la mediación documentaria se refiere a la mediación que se apoya en los dispositivos materiales o humanos capaces de relacionar la información y la comunicación. Se trata de una mediación de saberes que opera en la producción, difusión y apropiación de la información por un proceso de traducción, de conexión y de vínculo. Las autores citan a Régimbeau (2010) quien habla sobre la mediación entendida a partir de componentes de un proceso de comunicación que toma por objeto al usuario, las ideas, el contexto técnico, el contenido y a la práctica (social, económica, política...). La noción de mediación en juego implica que el sentido no es inmanente a las cosas sino que se construye por y para los sujetos. La mediación documentaria se realiza por medio de dispositivos calificados como dispositivos documentarios, por lo que, siguiendo las ideas de las autoras, la aprehensión de los procesos de mediación necesita una comprensión de los dispositivos que los sustentan.

Fabre y Gardies afirman que estudiar un dispositivo en su complejidad es comprender "[...] la naturaleza del vínculo que puede 
existir entre estos elementos heterogéneos" (citando a Foucault, 1997) (Fabre y Gardies, 2010: 4), colocando en su centro el concepto de "[...] comunicación que supone una organización, se basa en recursos materiales, moviliza competencias técnicas, define los marcos para la intervención y la expresión" (citando Jeanneret, 2005). (Fabre y Gardies, 2010: 4)

'Dispositivo' es entendido por las autoras, según Agostinelli (2009), como los artefactos que amplifican la comunicación, organizan la interacción humana y modifican los métodos de producción de gestión y de tratamiento de la información. El dispositivo documentario se encuentra organizado en torno a la gestión de la información relacionada con su soporte físico, el cual, aunque no se note a primera vista, no es independiente del discurso. De este modo, en el ámbito de las Ciencias de la Información y la Comunicación, el dispositivo es considerado dentro de un proceso social de comunicación.

En referencia a las categorías adoptadas por Meyriat para el concepto de documento, Fabre y Gardies elaboran la siguiente construcción. En su función de enunciación, el dispositivo documentario es calificado como dispositivo por intención. El dispositivo está diseñado y es organizado por los profesionales de la información quienes utilizan normas y se basan en saberes y técnicas con un fin particular: generar, organizar, procesar y difundir la información. En su función de apropiación, se convierte en un dispositivo por atribución; es decir, es reconocido por el usuario como portador de sentido, dentro del cual se le reconoce una información útil que responde a su necesidad de información.

Fabre y Gardies entienden que el dispositivo documentario, conocido en su origen como un dispositivo primario encargado de generar una masa de documentos, evoluciona muy rápidamente en un dispositivo secundario que realiza mediaciones documentarias. De esta manera esos dispositivos se sobreponen a los documentos, dispositivos primarios por esencia, y se interponen entre el usuario y las colecciones documentarias como parte del proyecto que pretende facilitar su acceso. Ellos constituyen un dispositivo secundario de 
vocación comunicacional que se unen al dispositivo informacional, llevando de esta forma a un dispositivo info-comunicacional.

El dispositivo info-comunicacional propone, por medio de una forma de enunciación, un lugar de estructuración de conocimientos así como de recepción y aprehensión de la información. Las dimensiones sociales y técnicas del dispositivo están constituidas por actores, técnicas y objetos materiales en permanente interacción y en un contexto definido. Según las autoras, para Couzinet (2008), el sentido genérico de las formas 'dispositivo informacional' y 'dispositivo comunicacional' fueron recientemente abordados bajo la expresión 'dispositivo info-comunicacional' para poner en evidencia la interdependencia entre la información y la comunicación. El dispositivo info-comunicacional, según Jeanneret (2005), citado por las autoras, es, en Ciencias de la Información y Comunicación, estudiado como objeto material mediador que designa el conjunto de sustratos materiales de la comunicación. Él es el enlace en el que humanos, objetos materiales y lugares se organizan para llevar a cabo las interacciones reales y simbólicas que establecen modalidades y lógicas de uso. Se trata de pensar en el modo necesario de seguir apoyando al usuario en su camino documentario en torno a la mediación, integrando el dispositivo info-comunicacional como verdadero dispositivo de aprendizaje, basado no solamente en las competencias relacionadas con las tecnologías de la información, sino también en la historia de sus soportes y sus lenguajes.

Fabre y Gardies destacan el problema de que la laguna entre las expectativas y necesidades de los usuarios y las representaciones de los creadores de los dispositivos digitales, conducen más a la innovación tecnológica que a una intención de mediación documentaria. Mencionan estudios (Fabre y Gardies, 2008, 2009) que muestran que hay una dificultad real para los usuarios en utilizar dispositivos cada vez más sofisticados, ya que, según Papy y Leblond (2009), citado por las autoras, estos dispositivos no muestran coherencia entre sí.

Sobre la afirmación de que ese concepto de dispositivo, característico de procesos de mediación documentaria no puede ser entendido como una organización lineal de operaciones mentales, las au- 
toras preguntan cuáles podrían ser las nuevas formas de mediación para relacionar esos nuevos dispositivos documentarios en un contexto de ausencia de coherencia.

A partir de la propuesta del dispositivo info-comunicacional, Fabre y Gardies proponen el término 'info-comunicacional' por considerarlo definidor de un proceso creador de un nuevo mensaje, cuyo signo es portador de una cierta materia informacional que le añade significados a la recepción. Si el circuito enunciación-recepción permite la circulación del sentido en situaciones de comunicación; es decir, de cambios, entonces la información es pre-existente a esa circulación e implica traducción, reescritura o estructuración, difusión y acomodación al medio, teniendo en cuenta el entorno y el eventual uso de la información. Incluso así, el sentido dado en la recepción no es predecible ni para el emisor ni para los eventuales mediadores. El objetivo es movilizar los dispositivos para convertir al usuario en actor de su cultura de información. De ese modo, el usuario tiene un lugar dentro del dispositivo sólo si se le invita a tomar la iniciativa y si la expresión de las diferencias individuales es alentada. Las autoras afirman que designarle un papel activo al receptor en la función informativa del documento, significa proporcionarle en ese momento la noción de uso, pero también la de mediación documentaria. Por otro lado, más adelante afirman que en los procesos de comunicación de la información, si el receptor juega un papel primordial, esto es en los casos donde no se trate de una simple transmisión, el mediador, por realizar procesos destinados a facilitar la apropiación de la información en el ámbito de comunicaciones sociales múltiples, también tiene un papel primordial.

Citando a Fabre y Couzinet (1996), las autoras afirman que el dispositivo documentario, visto bajo la óptica de la recepción, se convierte en pilar de la comprensión del saber o en un dispositivo de mediación capaz de ayudar a la construcción individual de conocimiento. Finalmente las autoras hacen énfasis en que es necesario repensar los procesos de mediación, teniendo en cuenta la complejidad de los dispositivos info-comunicacionales para comprender mejor la forma en que la información y la comunicación se relacionan con los fenómenos de apropiación de la información. 


\section{CONSIDERACIONES FINALES}

El enfoque francés sobre la mediación documentaria se muestra promisorio con respecto a una producción de conocimiento sobre la mediación desde el enfoque documentario, además de que hemos constatado que esto se ha realizado por varios autores organizados académicamente en busca de rigor científico frente al uso recurrente del término. Los autores franceses citados corroboraron nuestra problematización inicial cuando afirman que el mismo papel primordial atribuido al usuario le corresponde también a la mediación y al mediador, siendo el dispositivo info-comunicacional (que preferimos denominar dispositivo documentario) la base material de las actividades documentarias mediadoras que permiten la comunicación. Sin embargo, la literatura sobre el tema desde esta perspectiva todavía es incipiente para una comprensión de las actividades documentarias como acciones de mediación de la información. Tanto en Museología como en Bibliotecología es habitual encontrar la mediación sólo en las acciones finales que tienen lugar en una relación directa con el público, y por lo tanto desvinculadas de las distintas actividades realizadas sobre el objeto. La exposición, en el caso de la Museología; y los servicios de referencia y actividades conexas, en Bibliotecología, serían exclusivamente las acciones de mediación.

Finalmente podemos decir que la Documentación es el conjunto de actividades documentarias por medio de las cuales se realizan las acciones de mediación de la información. El término es derivado de la propuesta de Otlet y se volvió habitual en los servicios de información científica. Selección, producción de registros, conservación, divulgación y exposición son intervenciones realizadas sobre objetos teniendo presente un público para el que se hacen. De esta forma, la Documentación se convierte en un término significativo para comprender las actividades citadas, así como para poder entender por qué alcanzar el objetivo de la apropiación por el público depende de la realización fundamentada y metodológica de cada una de estas actividades y de la articulación entre ellas. 
Sin embargo, este enfoque no es del todo compartido y podemos encontrar, por ejemplo, en contraposición a lo que hemos venido diciendo, que el uso del término 'documentación' en Museología indica solamente la producción de registros en repertorios como listas o bases de datos. En general podemos decir que, con respecto a cada actividad documentaria, cuestionamos ideas comúnmente ya aceptadas como la de que la actividad de indización es propia de la Bibliotecología, y la de exposición es específica de la Museología, entre otras. Como guía común podemos afirmar que la identificación y la consolidación de cada actividad documentaria es el camino más productivo para distinguir entre los aspectos esenciales y los circunstanciales. Estos últimos que están constituidos según las condiciones históricas de las prácticas y de su elaboración manualística y dogmática, deben ser aprovechados a favor de una construcción epistemológica del área. De hecho, es rica y amplia la literatura técnico-científica que, reconociendo la diversidad de las prácticas profesionales, aborda varias actividades documentarias que fueron construidas de manera articulada y coherente, y van formando capas continuas de significado sobre el objeto.

El recorrido de la investigación para construir la noción de documento en el siglo XX permitió identificar puntos recurrentes tales como los siguientes: el documento es a la vez objeto físico (concreto, duradero, estable, manejable) e información (simbólico, conceptual, contenido de comunicación, de mensaje). La instancia informacional no es anterior al objeto pues los procesos interpretativos realizados por los intermediarios y/o por los 'lectores' finales es lo que hace que ocurra la existencia de un documento. La forma 'documentaire' en francés es emblemática de la propuesta otletiana sobre el documento. En Brasil, hay una fuerte herencia francesa a través de la forma 'documentario' para indicar los diferentes procedimientos e instrumentos, como: las actividades documentarias, los procesos documentarios y, en particular, los lenguajes documentarios (aunque el uso de los términos no sea riguroso en cuanto su origen conceptual). En Francia el término 'médiation documentaire' muestra la terminología que sustenta el enfoque adoptado para el tema que tratamos, ya que el término mediación de la información puede no 
implicar propiamente un trabajo sobre los documentos. Por otro lado, la forma española 'informativo-documental' y la forma francesa 'information-documentation' pueden considerarse redundantes, ya que 'documento' es un término que abarca la noción de soporte físico y de información o contenido atribuido. Una propuesta terminológica consistente y propia es no sólo rentable sino necesaria para un proyecto de fundamentación y consolidación científica. Por esta razón resaltamos la base terminológica fecunda que puede ser identificada en la literatura otletiana y que fue desarrollada en las siguientes décadas en torno al término 'documentación'. Son dignos de resaltar Meyriat y sus contemporáneos franceses quienes elaboraron alrededor de los años 1970 y 1980, una comprensión del documento guiada por el significado y la comunicación. Aunque poco consideradas, vale la pena enfatizar el rigor y la pertinencia de esas propuestas, además de su actualidad en función del carácter pragmático que presentan.

Las actividades documentarias por medio de las cuales las acciones de mediación son realizadas, incluyen procedimientos e instrumentos que son construidos localmente según el funcionamiento del lenguaje y según las terminologías de la especialidad adoptadas por el público (por tanto contemplando aspectos pragmáticos) y desarrolladas e implementadas por medio de políticas propias. El énfasis en el usuario fue tomando varios contornos con el trascurso del tiempo y actualmente se ha manifestado en proyectos colaborativos o de actuación directamente del mismo usuario en las actividades documentarias para construir el sistema. En tiempos de sobrevaloración de los llamados ambientes colaborativos, el papel de los usuarios debe ser debidamente enfrentado, ya que si no se considera el aspecto propositivo de las acciones de mediación de la información, entonces se puede terminar por perder justamente la posibilidad de contacto con el público.

De esta forma, resulta evidente la dificultad de una fundamentación teórica que haga justicia a los aspectos de procedimiento en juego, ya que muchas veces coloca en un segundo plano la instrumentalidad que corresponde con lo específico del área. Las actividades documentarias no son operaciones mecánicas, sino actos conscien- 
tes, establecidos profesionalmente sobre la base técnico-científica con un sesgo comunicacional. Estas actividades responden a prácticas profesionales de alta competencia que articulan la reflexión teórica con el dominio procedimental. La idea de neutralidad del proceso documentario, sustituida posteriormente por la de subjetividad, se muestra impedida para una práctica científica guiada por el establecimiento de criterios institucionales objetivos. La intencionalidad de las acciones de mediación de la información, propuesta inicialmente, puede ser comprendida a partir de enfrentarse con el objeto, en ausencia del cual puede haber un debilitamiento de la dimensión política de la institución, que se da, de acuerdo con Meneses, por medio de una enunciación en el contexto de un dispositivo documentario, por lo cual es calificado como un dispositivo documentario por intención, como lo desarrollaron Fabre y Gardies.

De esta manera podemos concluir que el documento es un producto. Es el resultado de un conjunto de acciones de mediación de la información. La 'producción del documento' se realiza a través de procedimientos metodológicos específicos que buscan promover las posibilidades de interpretación. La ruta del objeto al documento involucra abstracción que se realiza materialmente. Se trata de objetos colocados en otro lugar (simbólico) porque son seleccionados y recreados (materialmente) como representaciones de ellos; los documentos se hacen por las relaciones establecidas entre un objeto y otro, entre una representación y otra. 


\section{BIBLIOGRAFÍA}

Briet, S. (1951), Qu'est-ce que la documentation? París: Édit. 48 p., disponible en: <http://martinetl.free.fr/suzanneb riet/questcequeladocumentation/briet.pdf $>$. (Fecha de consulta: 1 junio 2015).

Buckland, M. (1991), "Information as thing", en Journal of the American Society for Information Science (JASIS), v. 45, núm. 5, pp. 351-360.

Couzinet, V. (2000), Médiations hybrides: le documentaliste et le chercheur de sciences de l'information, París: ADBS.

\& Régimbeau, G. \& Courbières, C. (2001), "Sur le document: notion, travaux et propositions", en Couzinet, V.; Rauzier, J.-M. (Col.), Jean Meyriat, théoricien et praticien de l'information-documentation, París: ADBS Éditions, pp. 467-506.

(Dir.) (2009), Dispositifs info-communicationnels: questions de médiations documentaires, París: Hermès science publications, (Systèmes d'information et organisations documentaires).

Després-Lonnet, M. (2014), "L'écriture du patrimoine, de la documentation à la mediation", Documentaliste-Sciences de l'Information, v. 51, núm. 2, pp. 61-62.

Desvallés, A. \& Mairesse, F. (Eds.) (2013), Conceitos-chave de Museologia. São Paulo: ICOM; Armand Colin, disponible en: <http://icom.museum/fileadmin/user_upload/ pdf/Key_Concepts_of_Museology/Conceitos-Chavede Museologia_pt.pdf $>$ (Fecha de consulta: 1 junio 2015).

Escarpit, R. (1991), L'information et la communication: théorie générale, París: Hachette Superiour. (Hachette Université Communication), publicado inicialmente em 1976 pela mesma editora. 
Fabre, I. (2012), "Médiation documentaire et culturelle dans le musée", Communication \& Langages, núm. 173, pp. 83-99.

(2013), "L'espace documentaire comme lieu de médiations", en Esquisse, disponible en: https://hal.archives-ouvertes.fr/hal-00837950/document. (Fecha de consulta: 1 junio 2015).

\& Gardiès, C. (2010), "La médiation documentaire”, en Liquète, V. Médiations, París: CNRS, pp. 121-139, (Les Essentiels d'Hermès).

\& Veyrac, H. (2008), "Des représentations croisées pour l'émergence d'une médiation de l'espace documentaire", en Communication E Langages, núm. 156, pp. 103-115, disponible en: http://oatao.univ-tou louse.fr/1938/1/fabre_1938.pdf. (Fecha de consulta: 1 junio 2015).

Frohmann, B. (2004), "Documentation redux: prolegomenon to (another) philosophy of information", en Library Trends, v. 52, núm. 3, pp. 387-407.

García Gutiérrez, A. L. (1999), "Aproximación al concepto y al objeto de la Información/Documentación", en García Gutiérrez, A. L. (Ed.), Introducción a la documentación informativa y periodística, Alcalá de Guadaira (Sevilla): Ed. Mad. pp. 23-35.

Gardiès, C. \& Fabre, I. (2012), "Définition et enjeux de la médiation numérique documentaire", en Galaup, X. (Org.), Développer la médiation documentaire numérique, Villeurbanne: Presses de l'ENSSIB. (La Boîte à Outils, 25), disponible en: <http://mediationdoc.enssib.fr/>. (Fecha de consulta: 1 junio 2015).

Jeanneret, Y. (2008), "Les relations entre médiation et usage dans les recherches en information-communication", en Colóquio mediações e usos de saberes e informação (1., 4-7 nov. 2008 : Rio de Janeiro, RJ). Anais. Rio de Janeiro: Rede MUSSI, pp. 37-59. 
Kobashi, N. Y. \& Tálamo, M. de F. G. M. (2003), "Informação: fenômeno e objeto de estudo da sociedade contemporânea", en TransInformação, v. 15, núm. 3 (ed. esp.), pp. 7-21, disponible en: <http://periodicos. puc-campinas.edu.br/seer/index.php/transinfo/article/ view/1458/1432>. Fecha de acesso: 1 jun. 2015.

Lara Filho, D. de (2009), "Museu, objeto e informação", en TransInformação, v. 21, núm. 2, pp. 163-169, disponible en: <http://periodicos.puc-campinas.edu.br/seer/index. $\mathrm{php} /$ transinfo/article/view/513/493>. (Fecha de consulta: 1 junio 2015).

Lara, M. L. G. de (2007), "A construção da informação no universo da linguagem na contemporaneidade", en Lara, M. L. G. de; Fujino, A. \& Noronha, D. P. (Orgs.), Informação e contemporaneidade: perspectivas. Recife: Néctar. pp. 143-168, disponible en: <http://www3.eca. usp.br/sites/default/files/form/ata/pos/ppgci/publicaco es\%20-\%20informacaoContemporaniedade $\% 281 \% 29$. pdf $>$. (Fecha de consulta: 1 junio 2015).

\& Ortega, C. D. (2012), "Para uma abordagem contemporânea do documento na Ciência da Informação", en Congreso ISKO 2011, Ferrol, 30 jun a 1 jul. 2011, [Anais]. A Coruña: Universidade da Coruña, pp. 371-387, disponible en: $<$ http://ruc.udc.es/dspace/bitstream/2183 /11621/1/CC_132_art_23.pdf >. (Fecha de consulta: 1 junio 2015).

Liquète, V. \& Fabre, I. \& Gardiès, C. (2010), "Faut-il reconsidérer la médiation documentaire?" Les Enjeux de l'information et de la communication, disponible en: $<$ https://hal.archives-ouvertes.fr/hal-00795148/docu ment>. (Fecha de consulta: 1 junio 2015). 
Mendes, L. C. (2013), "Transformações na percepção do museu no contexto do Movimento Bibliográfico: as concepções de museu de Paul Otlet e Otto Neurath", en Perspectivas em Ciência da Informação, v. 18, núm. 4, pp. 185-199, disponible en: <http://portaldeperiodicos. eci.ufmg.br/index.php/pci/article/view/1779/1215>. (Fecha de consulta: 1 junio 2015).

Meneses, U. T. B. de (1994), "Do teatro da memória ao laboratorio da história: a exposição museológica e o conhecimento histórico", en Anais do Museu Paulista, v. 2, núm. 1, pp. 9-42, disponible en: <http://www.scielo.br/ pdf/anaismp/v2n1/a02v2n1.pdf $>$. (Fecha de consulta: 1 junio 2015).

Meyriat, J. (1981), "Document, documentation, documentologie", en Schéma et Schématisation, $2^{\circ}$ trimester, núm. 14, pp. 51-63.

(2006), "Pour une compréhension plusisystémique du document (par intention)", en Sciences de la Societé, núm. 68, pp. 11-28 (Dossiê "Dimensions sociales du document", coord. por Caroline Courbières e Gérard Régimbeau).

Ortega, C. D. (2011), "Exploração de categorias configuradoras da ciência da informação", en Revista EDICIC, v. 1, núm. 1, pp. 183-205, disponible en: <http://www. edicic.org/revista/index.php?journal=RevistaEDICIC\& page $=$ article $\&$ op $=$ view $\&$ path $\% 5 \mathrm{~B} \% 5 \mathrm{D}=6 \&$ path $\% 5 \mathrm{~B} \% 5$ $\mathrm{D}=$ pdf_1 $>$. (Fecha de consulta: 1 junio 2015).

\& Lara, M. L. G. de (2010), "A noção de documento: de Otlet aos dias de hoje", en DataGramaZero: Revista de Ciência da Informação, v. 11, núm. 2, disponible en: <http://www.dgz.org.br/abr10/Art_03.htm>. (Fecha de consulta: 1 junio 2015). 
Otlet, P. (1934), Traité de Documentation: le livre sur le livre: théorie et pratique. Bruxelles: Mundaneum, disponible en: <http://lib.ugent.be/fulltxt/handle/1854/5612 /Traite_de_documentation_ocr.pdf $>$. (Fecha de consulta: 1 junio 2015).

(2007), El Tratado de Documentación: el libro sobre el libro: teoría y práctica, Trad. por Maria Dolores Ayuso García, Murcia: Universidad de Murcia, Tradução de: Traité de Documentation: le livre sur le livre: théorie et pratique.

Régimbeau, G. (2007), "Médiations iconographiques et médiations informationnelles: réflexions d'approche", en Communication, v. 26, núm. 1, pp. 164-177, disponible en: <http://communication.revues.org/875>. (Fecha de consulta: 1 junio 2015).

- (2010), "Médiation", en Gardies, C. (Dir.), Approche del'information-documentation: concepts fondateurs, Toulouse: Éditions Cépadues.

(2014), "Documents partagés", en Documentaliste-Sciences de l'Information, París, v. 51, núm. 2, pp. 44-45.

Rizza, M. (2014), "Document et musée: du discours sur l'oeuvre à la médiation culturelle", DocumentalisteSciences de l'Information, v. 51, núm. 2, pp. 28-29.

Sagredo Fernández, F. \& Izquierdo Arroyo, J. M. (1983), Concepción lógico-lingüistica de la Documentación, Madrid: IBERCOM. 


\title{
Dimensiones de los procesos de mediación del conocimiento. Contribución para un discurso interdisciplinario en ciencias de la información
}

\author{
Johann Pirela Morillo \\ Universidad de La Salle, Colombia \\ FRANCYS DELGADO \\ Centro de Investigación y Desarrollo \\ en Tecnologías del Conocimiento, CIDTEC \\ Universidad del Zulia-Venezuela
}

\section{INTRODUCCIÓN}

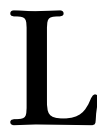

a Real Academia Española de la Lengua señala que el término mediación es la acción de mediar, lo cual proviene a su vez del latín mediare, que alude a acepciones enmarcadas en dos líneas de significación: una que tiene que ver con la mediación como interposición, y otra con ubicación en la mitad, lo que ocurre en dos momentos, lo que existe o está en medio de dos cosas; la otra línea de significación plantea la mediación como intercesión, actuar para la búsqueda de soluciones a situaciones problemáticas o el desarrollo de acciones que tienen el propósito de resolver conflictos. Este último significado del término enfatiza a la mediación como la búsqueda de un punto de equilibrio entre dos o más personas que riñen, y precisamente partiendo de la acción mediadora se pretende alcanzar la reconciliación y la armonía.

La línea de significación que consideramos en este trabajo es la que entiende a la mediación desde la idea de interposición y ubicación en medio de dos mundos o dos cosas con objeto de promover acciones que redunden en ganancia cognitiva e incremen- 
to del acervo de experiencias y de prácticas, por ello hemos estado defendiendo que la visión mediadora sea probablemente la que mejor ayude a interpretar la macro acción de las denominadas organizaciones de conocimiento y de los profesionales que las dirigen, de ahí que la asumamos como el componente transversal que puede contribuir con el proceso de unificación e integración del discurso epistemológico de las denominadas ciencias de la información.

Esta propuesta mediadora que estamos trabajando la vinculamos, además, con las nociones de información y de conocimiento, y planteamos entonces la mediación del conocimiento como el concepto nuclear en torno al cual habrá que generar una serie de sub-conceptos y categorías explicativas para fundamentar teórica y epistemológicamente los objetos y sujetos de estudio de las ciencias de la información, sobre todo en el actual momento histórico social, caracterizado por el uso intensivo de dispositivos tecnológicos, digitales e interactivos que pueden dinamizar aún más la creación, mediación y utilización de la información y del conocimiento en diversos procesos de la vida personal-social y académica-profesional.

Cabe mencionar que la perspectiva de la mediación, en tanto que interposición y existencia en medio de dos puntos, personas o mundos no sólo serviría para explicar teóricamente la naturaleza y alcance de la acción que se despliega desde las organizaciones de conocimiento, en particular, y de las ciencias de la información, en general, sino de cualquier otra organización social y sistema disciplinar o interdisciplinar que tenga dentro de sus objetivos fundamentales la explicación del acercamiento de dos ámbitos o personas, para maximizar procesos de apropiación y uso efectivo del conocimiento mediado.

Desde este argumento, son mediadores cognitivos no sólo los profesionales de la información (bibliotecólogos, archivólogos, documentalistas), sino también los comunicadores sociales, los educadores y demás profesionales que actúan como organizadores, intérpretes y promotores socio-culturales, críticos y significativos que se interponen entre el mundo de la cultura, de la ciencia, de la 
tecnología y del conocimiento, y los micro-mundos de las necesidades personales de información, formación y aprendizaje.

También serán organizaciones mediadoras del conocimiento, no sólo las bibliotecas, archivos y otros servicios de información y documentación, sino también las instituciones educacionales, los medios de comunicación, las redes sociales y otras organizaciones-dispositivos-plataformas que se interponen entre la cultura, la ciencia y la producción de ciencia y tecnología, y los actores sociales, quienes utilizan el conocimiento producido y mediado para lograr propósitos socio-culturales, educacionales, informacionales y comunicacionales.

En el marco de estas ideas, en este trabajo intentamos realizar una primera aproximación a las diversas dimensiones del proceso de mediación del conocimiento, con objeto de ofrecer los ángulos posibles de interpretación para entender el dinamismo y pluralidad del concepto, y su presencia transversal en diversos escenarios organizacionales y sociales; todo lo cual también podría ayudar a fundamentar una visión interdisciplinaria, compleja y ubicua de la mediación, que permita ver el concepto en su intersección con otros campos disciplinares como las ciencias de la educación, las ciencias de la comunicación y las ciencias cognitivas.

\section{DIMENSIÓN ONTOLÓGICA}

\section{DE LA MEDIACIÓN DEL CONOCIMIENTO}

La ontología es una disciplina filosófica que estudia el ser. Echeverría (2005: 28), se refiere al término en un sentido no metafísico, procurando salirse de la concepción griega y de lo que promulgaba Martin Heidegger, viéndola un poco como esa forma particular del ser humano de interpretar la realidad. El autor direcciona la ontología hacia el lenguaje, por que piensa que se pueden tener, indistintamente de la ontología metafísica, ontologías no necesariamente metafísicas que estén en el dominio de la interpretación. Echeverría se basa en tres postulados que tienen que ver con los seres humanos como seres lingüísticos, el lenguaje como generativo y la 
expresión de los seres humanos que se crean a través del lenguaje. Esta postura es interesante por cuanto sin lenguaje, nada sería posible. Pero queremos conectarnos con los procesos de mediación, por supuesto, dentro de esa necesidad de expresar y comunicar, pero también considerando que en estos procesos es el ser el principal mediador, y no podemos dejar a un lado esa conexión cuando la mediación se ve de forma empírica en el campo educacional, comunicacional e informacional.

Cuando hacemos referencia a los procesos de mediación del conocimiento, hemos pensado también en la perspectiva integracionis ta de la diversidad conceptual y partiendo de una vinculación en la relación sujeto-objeto donde cada sujeto asume la convicción de la verdad del proceso y de los elementos que lo integran. En cuanto a lo ontológico, es obvia la esencialidad del ente como tal, manifestada en las cosas en cuanto son, y en el ser que subyace en cada proceso de la bibliotecología, de las ciencias de la información, la documentación, o en cualquier otra denominación donde se analice el objeto de estudio de cada una de las disciplinas. A partir de la mediación se pretende la dialogicidad, como posibilidad de encontrar un punto convergente estratégico que sume voluntades a la diversidad.

La aprehensión del objeto per se, amerita el establecimiento de criterios, y de la forma como se perciba y asuma la realidad, desde el punto de vista ontológico se expresan claramente los problemas propios de la relación entre quien produce y quien recibe, pero en ese tránsito de inter-relación, hay derivaciones, tendencias, formas y maneras, a las cuales el ser humano muchas veces no está dispuesto a ceder, y no admite posiciones alternativas para actuar en la diversidad. Se presenta como afirma Rendón Rojas, (2005: 57), el "[...] problema del status ontológico de su objeto de estudio, de sus conceptos, enunciados, leyes y estructuras".

Es justamente en este proceso, donde la mediación se asienta, se proyecta al ser y dependiendo del tipo de mediación, la esencialidad de lo ontológico se fundamenta en esa conexión de mediar dos situaciones, dos mundos, dos seres o procesos. Echeverría (2005: 29), afirma: "Hagamos lo que hagamos, digamos lo que 
digamos, siempre se revela en ello una posible comprensión de lo que es posible para los seres humanos y, por lo tanto una ontología subyacente."

La ontología estudia al ser, sus relaciones y su existencia. En este caso y dado que en la mediación, quien interactúa es el ser, la concepción manejada por Echeverría sirve de orientación para aproximarnos al hecho de que en los procesos de mediación del conocimiento, se requiere de una comprensión de lo que verdaderamente significa el ser humano. Los procesos que se realizan no son ajenos al ser sensible y a ningún tipo de mediación.

La mediación en el plano de la ontología, nos induce a esa relación existencial del objeto, en cuanto éste es, y a la manera en que se comporta en esa intermediación. La postura ontológica le ratifica el ser, su existencia, lo visible, lo objetivable. La intervención de la mediación, es apreciativa. Significa en la praxis, explorar nuevas alternativas y maneras de concebir los procesos que se correspondan con las organizaciones representativas del conocimiento, donde se genera un intercambio con el interventor (sujeto), quien puede producir y reproducir conocimiento, y quien está muy vinculado con el aspecto cognitivo dada su capacidad transformadora, generadora que no tiene límites en el dominio del conocer y en su vinculación con el objeto tratante.

En el caso que nos ocupa, cada propuesta lleva implícito un sujeto involucrado en múltiples procesos que requieren dialogo para un manejo adecuado de las diferencias. Debemos ser mediadores de nosotros mismos y actuar en función de la reflexión, de la resolución y entender que las diferencias son complementos de nuestro pensamiento en la diversidad.

La dimensión ontológica la concreta Rendón Rojas (2005: 179), asumiendo que la bibliotecología tiene su fundamento ontológico en el ser del hombre, quien proporciona los elementos necesarios para conformar un proyecto existencial de vida; pues las relaciones informacionales se dan de manera independiente a la voluntad del ser humano; la bibliotecología se ubica dentro de las ciencias del espíritu. En esos cuatro fundamentos ontológicos habita el ser que conduce los procesos de mediación del conocimiento. Es el ser, podríamos 
decir, el gran mediador; justamente por su arraigo existencial, y su capacidad transformadora.

Las mediaciones que se exponen en esta investigación, se expresan en escenarios que podrían considerarse como independientes entre sí, pero que como fuerzas potenciales del conocimiento convergen en posiciones comprometidas y bajo expectativas diferentes, que a la hora de conciliar, ameritan un encuentro que no ancle las ideas, ni cercene el derecho interpretativo del ser. Es por ello que la dimensión ontológica busca la manera de percibir al ser en sí, en sus formas y maneras de interpretar la realidad.

En el marco de estas ideas, en este trabajo intentamos realizar una primera aproximación a las diversas dimensiones del proceso de mediación del conocimiento, con objeto de ofrecer los ángulos posibles de interpretación para entender el dinamismo y pluralidad del concepto, y su presencia transversal en diversos escenarios organizacionales y sociales; todo lo cual también podría ayudar a fundamentar una visión interdisciplinaria, compleja y ubicua de la mediación, que permita ver el concepto en su intersección con otros campos disciplinares como las ciencias de la educación, las ciencias de la comunicación y las ciencias cognitivas.

\section{DIMENSIÓN EDUCACIONAL DE LA MEDIACIÓN DEL CONOCIMIENTO}

Tal vez sea el educacional uno de los campos donde el concepto de mediación tenga un carácter central y estratégico, lo cual puede deberse a que las corrientes pedagógicas contemporáneas ven en este proceso y sus implicaciones, la acción medular a partir de la cual se promueven estrategias formativas que se vienen desplazando del protagonismo del docente hacia el protagonismo del estudiante, este último debe atribuirles nuevos significados a la información y el conocimiento mediados por el docente, sobre la base de lo cual se desarrollen competencias, vistas no sólo desde el ámbito de lo solamente laboral sino que se extienden hacia un enfoque integral, humanístico y social que conecte la acción com- 
petente con la excelencia personal en aras de generarle aportes significativos a la sociedad.

El concepto de mediación del conocimiento en el ámbito educacional está presente en diversas propuestas teóricas que le sirven de fundamento a este enfoque de las competencias personales y profesionales, el cual ha venido ganando terreno últimamente en los ámbitos de construcción teórica y de aplicación curricular de diferentes niveles y modalidades educacionales. La mediación está presente, sobre todo, desde las visiones teóricas que aluden a concepciones cognitivas hasta las visiones socio-culturales y constructivistas del aprendizaje, tales como las de Ausubel (1976) y Vigotsky (1979), entre muchos otros.

Los teóricos cognitivos como Ausubel (1976) entienden que el ser humano es un sistema de procesamiento de símbolos (cognición), llegando incluso a transformarlos, reorganizarlos y utilizarlos, con múltiples fines e intencionalidades, sobre la base de la acción mediadora que realiza el docente, quien debe preparar estrategias por medio de las cuales se logren aprendizajes cada vez más significativos y funcionales. El enfoque cognitivo enfatiza la potencialidad que tienen los alumnos para convertirse en aprendices estratégicos; es decir, en actores que aprendan cómo aprender y cómo resolver problemas.

En este sentido, se asume que la acción de enseñar-aprender es una acción de mediación a partir de la cual el profesor debe conocer o utilizar estrategias cognitivas, como por ejemplo: organizadores anticipados, resúmenes, analogías, mapas conceptuales y redes semánticas, cuya función también es mediadora y de representación e interpretación de los contenidos y coadyuve al logro de aprendizajes significativos. En palabras de Durán (2006), el enfoque cognitivo del aprendizaje asume la mediación como una acción programada y deliberada para permitir que los estudiantes experimenten, descubran y reflexionen sobre tópicos definidos de antemano, o que emerjan de las inquietudes de los alumnos, a través del apoyo y la retroalimentación continuas.

Otro de los enfoques educacionales, o mejor dicho psico-educacionales, donde tal vez se aprecie con fuerza el concepto de me- 
diación es en la Teoría socio-cultural de Vigotsky (1979), según la cual la relación entre el sujeto y el objeto de conocimiento se puede medir por la actividad que se realiza utilizando instrumentos socio-culturales, los cuales generan transformaciones en los objetos; dicha transformación es producto de mediaciones que los sujetos realizan para imprimirle nuevos significados al conocimiento con el cual se interactúa, teniendo como escenario los contextos socio-culturales e históricos en los cuales los individuos se insertan.

El enfoque vigotskiano tiene un fuerte matiz psicológico, al plantear que la acción mediada ocurre en el espacio donde interactúan los sujetos y los objetos con los denominados instrumentos socio-culturales mediadores, sobre cuya base se transforman las estructuras mentales. A partir de la acción mediada en interacción con el contexto socio-cultural, el sujeto construye-internaliza las funciones psicológicas superiores y la conciencia. De acuerdo con la visión de Durán (2006), el concepto de mediación es central en la obra vigotskiana y se materializa considerando instrumentos como el lenguaje en la interacción que los sujetos realizan con la cultura, a partir de lo cual se producen también procesos de apropiación.

Otros enfoques de la mediación, más orientados hacia la mediación cognitiva de modo puntual, son los que proponen Pilonieta (2004), Alegre (2005) y Cesca (2009), en los cuales se pone de relieve la centralidad de los procesos de interacción, y de modificabilidad permanente de las estructuras cognitivas.

Pilonieta (2004) define la mediación cognitiva como un acto de interacción que producen en la existencia de una persona: la flexibilidad, la autoplasticidad y la opción de activar procesos de modificabilidad permanente, logrando con ello la autonomía, la cual se considera como la meta de todo acto educativo; es decir, que los estudiantes sean cada vez más independientes en su proceso de aprendizaje. Alegre (2005) propone que la mediación se traduzca en facilitar la interacción social y la competencia en el aula, al exigir unas características y apuntar algunas estrategias para favorecer la competencia cognitiva del estudiante. 
Otro planteamiento de la mediación cognitiva es el que señala Cesca (2009), quien apunta que hablar de este concepto es hacer referencia a una interacción social como proceso en el cual es esencial el intercambio de significados entre dos o más personas, recalcando que deben existir para ello grados de bidireccionalidad y reciprocidad.

Puede observarse entonces cómo en el campo educacional, la mediación se asume como una de las categorías fundamentales a partir de las cuales se explica la acción de intervención educativa que debe ejercer el profesor para que los alumnos activen procesos de aprendizaje estratégico y significativo y de apropiación del conocimiento, con objeto de enriquecer su arsenal cognitivo y de prácticas.

\section{DIMENSIÓN COMUNICACIONAL DE LA MEDIACIÓN DEL CONOCIMIENTO}

Otra de las áreas donde el concepto de mediación se ha trabajado con especial énfasis es en las ciencias de la comunicación. Desde este ámbito de conocimientos encontramos a autores como MartínSerrano (1977), quien elabora una Teoría de la Mediación Social, que ofrece un nuevo objeto para las ciencias sociales: el estudio de la producción, transmisión y utilización de la cultura, a partir del análisis de los modelos culturales y de sus funciones. En realidad se trata de una teoría de la mediación inspirada en el proceso mediador de los medios masivos, los cuales elaboran representaciones de lo que sucede en el mundo, a partir de la selección de determinados mensajes.

Más recientemente, Martín Serrano (2007) retoma sus planteamientos pero destaca ahora la plasticidad que han asumido actualmente las mediaciones sociales en tanto que intervienen indistintamente en las acciones que preservan el mundo o lo ponen en riesgo, a través de las organizaciones que liberan u oprimen y en las representaciones que humanizan o deshumanizan, lo cual también forma parte de la complejidad de las denominadas sociedades de la 
información y del conocimiento, en las que surgen nuevas metáforas que pueden explicar el hecho de que a veces nos encontramos participando y otras no, de que las ventajas y la potencialidad que ofrecen las tecnologías de información y comunicación, están cada vez más centradas en la personalización y en la participación.

Otro enfoque de la mediación planteado desde la racionalidad comunicativa es el del conocido comunicólogo colombiano Martín-Barbero (1998), quien llega a postular el hecho de que la comunicación es un asunto de "mediaciones" más que de medios y a afirmar también que es una cuestión de cultura y no sólo de conocimiento, sino de reconocimiento, entendido éste como una operación de desplazamiento metodológico para volver a ver el proceso entero de la comunicación desde su otro lado, el de la recepción; es decir, el de la apropiación y los usos.

Las ideas del comunicólogo colombiano giran alrededor del concepto de receptor como ser activo, inteligente, con capacidad de interrumpir o resistirse, o de transformar o apropiarse de los mensajes de los medios, ya que éstos son mediados por los procesos de pensamiento, las luchas, y los placeres de la vida diaria con los cuales la gente constituye y reconstituye sus identidades. Es así que la hegemonía de los medios de comunicación se ve permeada por los contextos culturales con los cuales se negocian las identidades.

Ahora bien, es en ese momento de instalación y/o consolidación, más en unos contextos que en otros, de las denominadas ciberculturas o culturas digitales, vinculadas no sólo con el uso instrumental sino con la apropiación crítica de tales tecnologías, cuando las nociones que ayudan a explicar el concepto de mediación apuntan a incorporar otros referentes teóricos y empíricos. El enfoque de las mediaciones que Martín-Barbero propuso en 1998 como una apuesta por superar la visión meramente instrumental de los medios de comunicación, es considerado por Scolari (2008) para plantear el concepto de hipermediaciones, las cuales no aluden tanto a un producto o a un medio, sino a procesos de intercambio, producción y consumo simbólico que ocurren en un entorno caracterizado por una gran cantidad de sujetos (emisores-productores-receptores), 
medios y lenguajes interconectados tecnológicamente de manera reticular entre sí.

Otro autor que más recientemente ha trabajado el concepto de mediación es Fernández (2013), para quien el acceso a esa biblioteca universal, que es la Red, está ofreciendo y dando mayores oportunidades para seleccionar con más independencia cuáles mediaciones deseamos que se interpongan entre nuestro conocimiento directo y acontecimientos distantes. Las ideas de este autor no solo exponen lo ya conocido en cuanto a los beneficios y potencialidades de las redes para socializar y hacer más expeditos los canales entre quienes producen conocimiento y quienes lo necesitan, sino que su concepción se orienta hacia la divulgación de contenidos contestatarios respecto a discursos institucionalizados, lo cual ya fue expresado por Castells (2009).

Desde las revueltas moldava e iraní en 2009, hasta las recientes primaveras árabes en Túnez y Egipto, se ha puesto el énfasis en las posibilidades subversivas de algunas redes sociales como Twitter, LiveJournal o Facebook. Ello es recalcado por Fernández (2013), cuando expresa que los medios digitales de difusión podrían representar la oportunidad de romper más fácilmente con la mediación institucional que ligaba la esfera pública y las recepciones privadas. No se trata, pues, como aseguran las corrientes de pensamiento actuales, de un proceso de desintermediación de los cauces informativos. Al contrario, lo que está ocurriendo es una re-intermediación o, mejor dicho, una alter-mediación.

\section{DIMENSIÓN INFORMACIONAL DE LA MEDIACIÓN DEL CONOCIMIENTO}

La visión mediadora del conocimiento es un enfoque transversal que no nada más está presente en los ámbitos educacionales y comunicacionales sino también en otras áreas de las ciencias sociales dentro de las cuales se ubican, por supuesto, las denominadas ciencias de la información y sus perspectivas: bibliotecológica, documentalista, 
informacionalista y cognitiva, todo lo cual fue expresado por Delgado y Pirela (2013).

El trabajo bibliotecológico-documental-informacional tiene un matiz explicativo de corte mediador y comunicativo cognitivo, puesto que los procesos a los cuales se hace referencia desde los conceptos -que se realizan en las denominadas organizaciones de conocimiento (bibliotecas, archivos, centros de documentación, servicios de información)- pueden concebirse como acciones de mediación; y en este sentido, la concepción de interposición y ubicación en la mitad de dos actores, dos cosas o dos mundos, a la cual nos referíamos acudiendo a la fuente etimológica del término, es de vital importancia para comprender la naturaleza y alcance de este concepto en las ciencias de la información.

Tanto las propuestas teórico-conceptuales de corte bibliotecológico, como las documentalistas y propiamente informacionales convergen para entender que la mediación del conocimiento es el proceso medular que hace posible la accesibilidad y disponibilidad de la información: norte de las organizaciones de conocimiento y finalidad de la función profesional en esta área.

Para Pirela (2013), la mediación del conocimiento se define como un proceso macro mediante el cual se generan acciones sistemáticas de intervención entre el espacio de la producción de mensajes y contenidos intelectivos, y su recepción crítica y significativa por parte de usuarios en estados de total reciprocidad, lo cual implica que los sujetos emisores y receptores críticos intercambien saberes, experiencias y demuestren dominio de competencias, para apropiarse de la información, y agregarle valor y nuevos significados.

Con objeto de representar teórica y metodológicamente la mediación que se realiza en las denominadas organizaciones de conocimiento (uno de los espacios empíricos de las ciencias de la información), se ha considerado una versión sintética que Pirela (2004) había considerado sobre dicho proceso, y se ha llegado a definir un sistema conceptual explicativo sobre los procesos de mediación en las organizaciones de conocimiento de la cibersociedad. Dicho sistema está constituido por macro, meso y micro-componentes. 
Los macro-componentes están constituidos por: categorías conceptuales orientadoras; los meso-componentes aluden a un modelo de mediaciones cognitivas múltiples y los micro-componentes se traducen en lineamientos para concretar prácticas de mediación en los servicios de información.

En cuanto a los macro-componentes del sistema se tienen categorías conceptuales como: ubicuidad, reticularidad y apropiación socio-crítica de la información, y aquellas tecnologías que más explican la naturaleza, alcance e impacto de la mediación del conocimiento en el ámbito de las ciencias de la información.

La ubicuidad se define como una de las principales propiedades de la información y el conocimiento en la cibersociedad. La información está en muchas partes a la vez y fluye a través de diferentes nodos, lo cual plantea que la construcción del conocimiento parte de una lógica que implica la presencia múltiple y abarcadora de la información en la sociedad, gracias a las redes socio-informativas y digitales. Una información puede ser accedida e interpretada a un mismo tiempo real y en diferentes puntos ubicados espacialmente.

La reticularidad es un principio que debe orientar la acción mediadora en las organizaciones de conocimiento de la cibersociedad, porque el conocimiento con el cual se trabaja en estas organizaciones se produce muchas veces a partir no sólo de la interconexión de redes tecnológicas, sino también, y de un modo mucho más importante, de la acción de redes sociales (grupos de investigación, y grupos organizados para el procesamiento de la información, dedicados a la acción ciudadana), cuyo acceso es posible gracias a Internet, y también a los productos hipermediales y virtuales que hacen cada vez más interactivos y holísticos los procesos asociados con el tratamiento de la información y la organización del conocimiento. La concepción reticular como principio orientador introduce también la idea de "conocimiento redificado" planteada ya por Caballero (2000), según la cual los sujetos conectados por las redes comparten sus inteligencias y formas de aproximarse al mundo.

La tercera categoría es la de apropiación social y crítica de la información y las tecnologías, la cual puede definirse como un proceso para cuya realización es imprescindible el desarrollo de 
acciones de alfabetización informativa y tecnológica, en virtud de que hoy día, se está requiriendo cada vez más no sólo "saber utilizar y darle significado a la información", en su sentido más amplio, sino también hacerlo por medio de los medios digitales, lo cual requiere de un entrenamiento sistemático y sostenido desde la educación formal y desde las organizaciones del conocimiento.

La garantía del acceso igualitario, más la apropiación social y crítica de la información y las tecnologías, son la base de la construcción colectiva de una sociedad del conocimiento centrada en la persona y en el incremento del arsenal intelectual, ya que no se trata sólo de invertir en la conexión telemática, sino también en la formación del ciudadano para dotarlo de las habilidades que le permitirán convertirse en un usuario receptor activo y crítico; es decir, en un mediador significativo de la información y del conocimiento que fluye en distintos niveles y medios a través de la sociedad.

Los meso-componentes del sistema están integrados por un modelo de mediaciones cognitivas múltiples, que asume que en el ámbito de la producción de conocimiento y de su recepción activa y crítica se dan múltiples y complejas mediaciones porque ocurren en el contexto de tres dimensiones: la del emisor de primer orden (los autores y productores de información y conocimiento), donde se da la primera mediación; la del emisor de segundo orden (profesional mediador de información), y la del usuario, quien debe realizar una recepción crítica y activa. Esto último depende de su formación para "dominar" y "recrear" la información, y del uso crítico que haga de las tecnologías.

Los micro-componentes del sistema conceptual explicativo plantean lineamientos para concretar las mediaciones a partir del diseño de productos y servicios de información, cuyo proceso es la investigación y detección sistemática de necesidades de información, conocimiento y aprendizaje. En la sociedades de la información y del conocimiento no sólo interesa saber qué información requiere un determinado usuario, sino también cuáles son sus preferencias en cuanto a presentación y procesamiento de información, lo cual incorpora la caracterización de perfiles cognitivos de los usua- 
rios, y también tiene que ver con sus estilos de pensamiento y de aprendizaje.

Cabe mencionar que la dimensión informacional de la mediación del conocimiento fue pensada desde la praxis profesional en las denominadas organizaciones de conocimiento, como uno de los espacios empíricos de las denominadas ciencias de la información. El resto de las dimensiones expuestas, aunque fueron construidas desde otros ámbitos teórico-metodológicos de conocimiento, como el educacional y el comunicacional, aportan, sin duda, conceptos y principios que nutren la compresión de la naturaleza y el alcance de las ciencias de la información, sus organizaciones mediadoras y sus profesionales.

\section{CONCLUSIONES}

Para profundizar en la naturaleza y alcance de los procesos de mediación del conocimiento es necesario identificar rasgos y principios de este proceso partiendo desde la racionalidad propia de las denominadas ciencias de la información, pero también de otros campos disciplinares como las ciencias de la educación y de la comunicación. Sólo que antes de emprender esa tarea se requiere profundizar en los fundamentos ontológicos de tales procesos, en tanto que se interponen entre la acción que los seres humanos realizan para interpretar la realidad circundante.

La visión ontológica de los procesos de mediación del conocimiento se fundamenta en esa conexión que implica la interposición de dos situaciones, dos mundos, dos seres o procesos. La mediación supone habilitar espacios para la interconexión, sobre la base de la necesidad de expresar y comunicar, pero también considerando al ser como el principal mediador, y no podemos dejar a un lado esa conexión cuando la mediación se ve de forma empírica en el campo educacional comunicacional e informacional.

Desde el campo educacional, los procesos de mediación del conocimiento se asumen como una de las categorías fundamentales 
a partir de las cuales se explica la acción de intervención educativa que debe hacer el profesor para que los alumnos activen procesos de aprendizaje estratégico, significativo y de apropiación del conocimiento, con objeto de enriquecer el arsenal cognitivo y de prácticas. El profesor se entiende como preparador, organizador e intérprete de los estímulos y significados que rodean el ámbito socio-cultural, científico y tecnológico, y la acción de educar se desarrolla a partir de complejos procesos mediadores orientados a dotar a los estudiantes de las herramientas para acceder a la información y construir permanentemente el conocimiento agregando nuevos significados.

El ámbito comunicacional concibe que los procesos de mediación del conocimiento deben apuntar, en este momento, hacia la apropiación crítica de las tecnologías de información y comunicación, noción que lleva a ubicar la mediación en una perspectiva estratégica, conectada con la posibilidad de construir ciberculturas; ello plantea a su vez la necesidad de superar la visión meramente instrumental de los medios de comunicación para considerar las denominadas hipermediaciones y altermediaciones, las cuales no aluden tanto a un producto o a un medio, sino a procesos de intercambio, producción y consumo simbólico que ocurren en un entorno caracterizado por una gran cantidad de sujetos (emisores-productores-receptores), y medios y lenguajes interconectados tecnológicamente de manera reticular entre sí, todo lo cual está dinamizando y ampliando las posibilidades de participación socio-política y trayendo a la palestra a los denominados nuevos grupos, quienes encuentran en las redes sociales y los medios digitales nuevas formas de visibilidad y expresión.

Por último, la perspectiva de los procesos de mediación desde lo informacional apela a una concepción interdisciplinaria y transversal que conduce a resaltar el hecho de que el trabajo bibliotecológico-documental-informacional tiene un matiz explicativo de corte mediador y comunicativo cognitivo, puesto que los procesos a los cuales se hace referencia desde lo conceptos -que se realizan en las denominadas organizaciones de conocimiento (bibliotecas, archivos, centros de documentación, servicios de información)- pueden concebirse como acciones de mediación y, en este sentido, es per- 
tinente la concepción de interposición y ubicación en la mitad de dos actores, dos cosas o dos mundos.

Para la necesaria construcción de un discurso epistemológico unificado en las ciencias de la información se requiere, entonces, abordar diferentes aristas desde donde se entiendan los procesos de mediación, en tanto que elementos-procesos que pueden ayudar a unificar-integrar dicho discurso. El carácter de conexión no solo disciplinaria sino interdisciplinaria que tienen los procesos de mediación del conocimiento permitirán contribuir con la tarea impostergable de generar cuerpos explicativos, interdisciplinarios también, que den cuenta de tales procesos y de su relación no sólo con la teoría en el área sino con su práctica.

\section{BIBLIOGRAFÍA}

Alegre, J. (2005), El profesor mediador. Disponible en: http://www.formaciondidactica.com/mediador.pdf (Fecha de consulta: 16 de abril 2013).

Ausubel, D. P. (1976), Psicología educativa: un punto de vista cognoscitivo, México: Trillas, Traducción al español de Roberto Helier D., de la primera edición de Educational Psychology: A Cognitive View.

Caballero, S. (2000), Organizaciones emergentes que surgen en el ciberespacio, Tesis Doctoral, Centro de Estudios del Desarrollo (CENDES). Universidad Central de Venezuela, Caracas-Venezuela.

Castells, M. (2009), Comunicación y poder, Madrid: Alianza.

Cesca, P. (2009), La mediación cognitiva. Un estilo de aprendizaje para enseñar a pensar, disponible en: http:// www.delasallesuperior.edu.ar/biblioteca/mediacion_cog nitiva_noveduc.pdf. (Fecha de consulta: 16 de mayo 2012). 
Delgado, F y Pirela, J. (2013), "Los procesos de mediación del conocimiento como elementos integradores-unificadores del discurso epistemológico de las ciencias de la información", en El objeto de estudio de la Bibliotecología/documentación/ciencia de la información: propuestas, discusión, análisis y elementos comunes, Coordinador. Miguel Ángel Rendón Rojas, México: Universidad Nacional Autónoma de México, (UNAM), Instituto de Investigaciones Bibliotecológicas y de la Información, 295 p.

Durán, T. (2006), Curso-Taller: Corrientes pedagógicas contemporáneas, Ciudad Juárez: Universidad Autónoma de Ciudad Juárez-México.

Echeverría, R. (2005), Ontología del Lenguaje, 5ta. ed. Santiago: Edit Comunicaciones Noroeste.

Fernández, A. (2013), "Altermediaciones: resistencias en medios digitales", en Diálogos de la comunicación, Revista Académica de la Federación Latinoamericana de Facultades de Comunicación Social (FELAFACS), núm. 86. enero-julio 2013, disponible en: http://www.dialo gosfelafacs.net/wp-content/uploads/2013/01/86_Revis ta_Dialogos_Alter-mediaciones.pdf (Fecha de consulta: 8 de diciembre 2013.)

Martín-Barbero, J. (1998), De los medios a las mediaciones. Comunicación, cultura y hegemonía, Bogotá, Colombia: Convenio Andrés Bello.

Martín-Serrano, M. (1977), La mediación social, MadridEspaña: Ramón Akal Rodríguez Editor.

(2007), Prólogo para La Mediación Social en la era de la globalización, disponible en: http://pendiente demigracion.ucm.es/info/mediars/MediacioneS1/Indice/ MartinSerrano/martinserrano.html. (Fecha de consulta: 5 de mayo 2013). 
Pilonieta, G. (2004), "Modificabilidad Estructural Cognitiva”, en Revista Magisterio, disponible en: www.colom biaaprende.edu.co/.../article-74538 (Fecha de consulta: 8 de julio 2013).

Pirela, J. (2004), Los procesos de mediación en las organizaciones de conocimiento de la cibersociedad, Tesis doctoral, Programa de Doctorado en Ciencias Humanas, Universidad del Zulia, Maracaibo-Venezuela.

(2013), "La mediación del conocimiento en el perfil por competencias del profesional de la información", Ponencia presentada en el VI Encuentro Ibérico. EDICIC 2013, en Globalización, Ciencia e Información, Actas, disponible en: http://www.youblisher.com/p/745142-VIEncontro-Iberico-EDICIC-2013-Globalizaçao-Ciencia-Infor maçao/ pp 209-219. (Fecha de consulta: 13 de enero 2014).

Rendón Rojas, M. (2005), Bases Teóricas y Filosóficas de la Bibliotecología. 2da. ed., México: UNAM, Centro Universitario de Investigaciones Bibliotecológicas.

Scolari, C. (2008), Hipermediaciones. Elementos para una Teoría de la Comunicación Digital Interactiva, Barcelona: Gedisa, 317 p.

Vygotsky, L. S. (1979), El desarrollo de los procesos psicológicos superiores, Buenos Aires: Grijalbo. 


\title{
Mediação e filosofia da ausência: a invenção gramatical da "mediação humana" e super-ação do humano ${ }^{1}$
}

\author{
Gustavo Silva Saldanha \\ PPGCI/IBICT-UFRJ \\ PPGB UNIRIO
}

\section{PRIMEIRAS INTEPRETAÇÕES}

Ouvir falar é antes de tudo ser surdo à diversidade de ruídos (AUROUX, 1998: 30)

\begin{abstract}
proposta deste trabalho é discutir as relações entre lingua$\Delta$ gem, mediação e técnica a partir da filosofia da linguagem. - 1 Tendo como linha metodológica a aproximação a uma hermenêutica epistemológico-informacional, como nos convoca Rafael Capurro, elaboramos uma reflexão filosófica sobre a construção das "coisas" a partir da linguagem e seus impactos na produção das ideias acerca do conceito de mediação no escopo da Ciência da In-
\end{abstract}

1 A reflexão filosófica aqui manifestada é fruto do desenvolvimento do projeto de pesquisa "Trilhar o trivium: a Filosofia da Ciência da Informação na tradição filosófica da linguagem" que conta com financiamento do Conselho Nacional de Desenvolvimento Científico e Tecnológico (CNPq) e da Fundação Carlos Chagas Filho de Amparo à Pesquisa do Estado do Rio de Janeiro (FAPERJ). O trabalho também integra o fórum de discussões desenvolvido no grupo de pesquisa brasileiro "Ecce Liber: filosofia, linguagem e organização dos saberes". 
formação e da filosofia da informação. Buscamos observar como a separação produzida pelos argumentos representacionistas sobre a linguagem provocam a fundação de dicotomias, como fora e dentro, humano e técnica, cultural e tecnológico, que afastam a compreensão epistemológico-histórica da noção de "mediação" entre Filosofia e Ciência da Informação, desembocando na fronteira de confronto de uma filosofia da presença e de uma filosofia da ausência nos estudos informacionais. À procura por estabelecer uma discussão crítica sobre estas dicotomias, debatemos a produção gramatical da realidade simbólica, propiciada em nossa epistême pela escrita, a partir de uma aproximação aos pensamentos de Jacques Derrida e Sylvain Auroux, "conciliados" a partir de Barbara Cassin e de Ludwig Wittgenstein. $\mathrm{O}$ argumento geral está em apreender a noção de ação, da pragmática, como centralidade das práticas de mediação, a partir do entendimento da constituição gramatical da noção de "mediação humana".

Encontramos, de um lado, as construções sobre os problemas inerentes à mediação, concernentes ora à questão das "mediações da presença", com o fundo falso de "humanismo das Humanidades", ora aos desafios das "mediações da ausência", fundadas no uso de tecnologias para as trocas, as transmissões e as apropriações de elementos da linguagem. O primeiro caso remete à constante logocêntrica abordada por Derrida (2008), que marcaria, na visão do filósofo francês, a história da filosofia ocidental, de Platão aos antropólogos do Oitocentos e do Novecentos. O segundo caso nos levaria ao "terror" da máquina e a depreciação das tecnologias da linguagem como fontes atávicas ao conhecimento, à memória e à compreensão do real.

Se no Fedro de Platão estas possíveis aporias são lançadas, fazendo do Ocidente filosófico "devedor" da questão (e, em geral, adepto do segundo caso), a ética cristã e sua vasta influência nos dois milênios que nos distanciam do classicismo grego nos apontam para uma direção próxima.

A Gênese, no Antigo Testamento contém e que remonta provavelmente a um velho fundo legendário sumério, procede em dois 
tempos: de um lado, Adão dá nome aos animais e às coisas, o que explica a primeira língua e o privilégio da humanidade; de outro, Deus, colocando fim à construção da Torre de Babel, dá origem à primeira diversidade de línguas. (Auroux, 1998: 29, grifo nosso)

É a partir da "presença" de Deus "entre nós", da "presença" de Adão "entre os homens", que a mediação (pela linguagem, aqui entendida como processo de representação filosófica, antes de informacional, entre o conhecimento e sua explicitação) não só se efetiva; ela nasce ali, e nasce assim, como uma manifestação (epifânica) do "estar" junto do "ser". Este é o espaço-tempo que Derrida (2008) aborda como "filosofia da presença" e o "imperialismo da fala". Tal potência-mor do pensamento ocidental pode ser repensada com uma visão da escrita e das noções de tecnologias da linguagem, incluindo a categoria da oralidade não como poder dissociado de outros instrumentos, mas também como técnica. E neste caso passamos a tratar do jogo entre a mediação filosófica e nosso interesse nos estudos informacionais: a ação do eu-mediador do conhecimento já manifesto e o conjunto potencial de intersujeitos que podem se apropriar de tais manifestações.

O aparecimento da "escrita", e não da "linguagem", como nos atenta Auroux (1998), pode ser tratado como a pioneira revolução tecnolinguística, na medida em que abre o "espaço" (isto é, concebe o "reflexo espacial") para o observar, o admirar, o contemplar e, fundamentalmente, o "refletir sobre o reflexo" da própria linguagem. Esta revolução é acompanhada por uma segunda, dependente da primeira, identificada a partir da noção de "gramatização", sendo acompanhada por uma terceira, contemporânea, que agregaria ambas a partir de diferentes princípios tecnológicos. Tratar-se-á, esta última, da linguagem no contexto das técnicas eletrônicas. Nas palavras do filósofo da linguagem

[...] a primeira revolução tecnolinguística foi a invenção da escrita, cujos efeitos foram amplificados com a criação da imprensa. A segunda foi a gramatização das diferentes línguas do 
mundo, amplificada ela também pelo estabelecimento de políticas linguísticas nacionais e da alfabetização. Parece dificilmente contestável que sejamos contemporâneos da terceira grande revolução nesse domínio, a do tratamento eletrônico da informação apresentada na linguagem natural. Trata-se verdadeiramente de uma mecanização das formas privilegiadas da comunicação humana. (Auroux, 1998: 289, grifo nosso)

Em nosso ponto de vista, estas três revoluções podem ser entendidas, se nos aproximarmos da tentativa epistemológica da Gramatologia de Derrida (2008), de um amplo percurso de gramatização, que vivenciou não apenas três, mas diversos momentos (extra)ordinários ao longo da história humana, onde "escrita" e "tecnologias eletrônicas" compõem parte ínfima (ainda que mutante) de uma série de elementos atiçadores da revolução. O próprio Auroux (2009) procura demonstrar a ampla "revolução tecnológica da gramatização", sendo aqui "gramática" um conceito muito anterior à revolução específica e pontual, de fundo político-bélica, de gramatização das línguas nacionais.

Buscamos demonstrar como a questão, presente no pensamento, por exemplo, de Gabriel Peignot (1802a, b) e Paul Otlet (1934), é estrutural para os estudos informacionais, sendo, deste modo, elemento delineador da questão epistêmico-informacional da mediação. Podemos também perceber esta relevância, de modo mais flagrante, nos movimentos epistemológicos recentes no campo, como aqueles oriundos do pensamento de Rafael Capurro (1992) e de "neodocumentalistas" como Frohmann (2004, 2011), Day (2005) e Buckland (1991, 1997). Percebemos que a questão está no centro de debates contemporâneos dos estudos informacionais, como competência informacional, organização do conhecimento a partir de e através das redes eletrônicas, educação à distância, a filosofia da informação entre Rafael Capurro e Luciano Floridi e, em nosso enfoque, a noção de mediação. 


\title{
A INVENÇÃO DA "MEDIAÇÃO TÉCNICA": WIENERISMO DO FEDRO E O "FIM" DA FILOSOFIA DA PRESENÇA
}

\author{
O que é peculiar ao livro [...]: o \\ pensamento posteriormente fixado \\ pela escritura ou pela imagem das \\ coisas, dos signos visíveis, fixado em \\ um suporte material.
}

(OTLET, 1934: 10)

Procuramos reconhecer uma margem possível (e não natural), uma fronteira de elaboração sócio-histórica (e não um limite), para o momento de invenção da "mediação técnica" como contraposto da "mediação humana", para caracterizarmos, de fato, no escopo da epistemologia da Ciência da Informação e da filosofia da informação, a condição epistemológico-histórica que nos interessa, de fundo gramatológico (conforme uma possível brecha de aproximação entre os pensamentos de Auroux (1998) e de Derrida (2008)): o problema da invenção da "natureza" da "mediação humana". Esta invenção parece estar (radicalmente) indicada em Norbert Wiener (1989), em The Human Use of Human Beings, obra de 1950, de fundo mais reflexivo, que viria para sanar as dúvidas do discurso sobre a técnica apresentado em 1948, o clássico Cibernetics. Sua radicalidade é apenas o desdobramento do longo embate lançado pelo Fedro platônico. Tanto Derrida (2008) quanto Wiener (1989) reportam-se, por exemplo, a Leibniz, onde está a compreensão esclarecida entre homem, linguagem e "extensão", círculo conceitual que pode ter um nó comum: a técnica. Entretanto, o recuo ainda pode dirigir-se a outra possível estaca zero: a própria sofística e sua disputa com Sócrates, como veremos a seguir.

Descortinadas as raízes do embate filosófico entre idealidade e ordinariedade, e aplicados os estudos e as práticas informacionais nestes bastidores desvelados, perceberemos que nosso interesse epistêmico sempre esteve mais vinculado ao problema da invenção maquínica (técnica) da "mediação humana", que à "praga" lançada pelo Fedro de Platão sob e sobre a "mediação técnica". Adentrando o vocabulário de Derrida (2008), o jogo entre presença e ausência 
nos estudos informacionais sobre mediação torna-se restrito, quando delimitados e focalizamos a linguagem como técnica ou, mais precisamente, as técnicas da linguagem.

Compreender que nosso problema epistêmico (a confusão) está em como criamos a possibilidade (quase metafísica, mesmo nos tempos atuais) de valorização da mediação da presença (relacionando necessária e equivocamente, a "presença" com o humano, a "voz" com a verdade, o "estar" com o ser), torna-se o dilema epistemológico em aberto não apenas para rever o papel da técnica a partir da linguagem. Principalmente, o aspecto nos leva a pensar a super-ação, ou a) a dinâmica das ações de práticas intersubjetivas que envolvem os registros do conhecimento e b) o apagamento das relações dicotômicas entre homem e máquina.

A questão central para uma argumentação acerca da faticidade do discurso sobre mediação está nesta última dicotomia. Ela é apresentada, em geral, pelo jogo de relações ora conflituosas, ora co-partícipes, de mediação humana e mediação técnica. Esta questão tem uma morada clássica: o Fedro de Platão. Aqui, a dialética sobre a Beleza tem um de seus limites centrais na linguagem e na ação do retor. Thoth (ou Theuth), Deus egípcio da escrita, também chamado Ámon, inventou os caracteres gráficos, ou seja, nos presenteou de uma só vez a Matemática e a Gramática. O mito do aparecimento da escrita em Thoth, lançado sob a hermenêutica aurouxiana, nos permite a compreensão sócio-histórica do feitiço da linguagem (enquanto técnica):

Não conhecemos civilização oral que tenha desenvolvido técnicas calculatórias, mesmo elementares como nossas operações de adição e de subtração. A maior parte das línguas unicamente orais e sem contatos com civilizações grafematizadas dispõe somente de um sistema de numeração restrito. $O$ cálculo só se tornou possível através do recurso a elementos externos, e até objetos técnicos como os bouliers (tabela gráfica que permite facilitar muitos cálculos) ou os abaques (ábaco, tabela de calcular da Antiguidade, tornada no século X uma tabela de colunas - dezenas, unidades, centenas - que utiliza cifras). De maneira geral, a escrita parece ser a condição de seu desenvolvimento. (Auroux, 1998: 73, grifo nosso) 
Não apenas os signos gráficos usados para o imediato da fala, mas "os algoritmos e o infinito matemático são inconcebíveis sem a escrita" (Auroux, 1998: 74), ou seja, estamos diante uma tecnologia que impulsiona um conjunto inumerável de transformações sócio-históricas. É neste ponto que o objeto em questão se torna pauta central da Filosofia e Platão utiliza sua dialética (fonética) para demonstrar os problemas desta mediação.

A invenção mitológico-egípcia da escrita surge, pois, como um entrave para o conhecimento, ou, mais radicalmente, como uma antítese ao real. A arte da escritura seria um veneno, uma espécie de medicamento que poderia, em um primeiro momento, sugerir a cura (principalmente para a memória e para o ensino, mas, por intenção ou extensão, para o pensamento). Porém, seu uso disseminado resultaria na própria contradição, ou seja, destituição da memória, atrofia das possibilidades do pensar. Em outros termos, o aparecimento da escrita como problema filosófico é a sua "expulsão" da Filosofia como possibilidade de aproximação ao real. Mimese que é, por natureza, nessa leitura, a linguagem e seu espelho imitado, a escrita, só poderia nos conduzir ao afastamento da verdade - distamos do mundo inteligível na medida em que nos dedicados a pensar a partir do mundo material, e a escrita torna-se sinônimo ideal no $\mathrm{Fe}$ dro de um completo obscurecer do real.

O Fedro marca a condenação de uma "filosofia da ausência", uma filosofia das mediações técnicas, em prol de uma teoria do conhecimento baseada no "coletivo que dialetiza", que debate no espaço tornado público. A fala -mais precisamente, as falas, na relação dialética- é a condição do filosofar, contra o discurso, relação de verticalidade do um para muitos. Mesmo com a ênfase no metamaterialismo linguístico, Paul Otlet (1934: 85) é traído por esta aporia: o advogado belga recupera Platão para, concordando, afirmar que só a fala é plenamente viva, quando todo o seu Traité edifica-se como uma apologia do materialismo do conhecimento manifesto no mundo sensível.

Se tal aporia do Fedro estaria ("resolvida") na distante compreensão de Norbert Wiener, a arte do piloto, a arte de manusear, de manipular, ela, no fundo, apenas descortina o campo informacional 
em sua jornada bibliológica. A extensão do homem tendo a máquina como partícipe de sua pretensa "natureza" esclarece que a "passagem" do humano para o maquínico não se dá de maneira alguma abrupta. A máquina é tão "humana", quanto o "humano" é "maquínico" - entre outras palavras, trata-se de uma poiesis do humano. Contra o argumento, no entanto, se deu nosso decurso ocidental:

Já se pressente, portanto, que o fonocentrismo se confunde com a determinação historial do sentido do ser em geral como presença, com todas as subdeterminações que dependem desta forma geral e que nela organizam seu sistema e seu encadeamento historial (presença da coisa ao olhar como eidos, presença como substância - essência - existência (ousia), presença temporal como ponta (stigmé), consciência, subjetividade, co-presença do outro e de si, intersubjetividade como fenômeno intencional do ego etc.). (Derrida, 2008: 15, grifo nosso)

Derrida (2008) desenvolverá uma compreensão crítica desta filosofia em sua procura epistêmica por uma certa Ciência Gramatológica: a favor da phoné o Ocidente se constituiu, tendo, sob este solo filosófico, elaborado inúmeras instâncias contrárias e contraditórias, mas sempre tendo a fala como o modelo, a estrutura.

O privilégio da phoné não depende de uma escolha que teria sido possível evitar. Responde a um momento da economia (digamos, da 'vida' da 'história' ou do 'ser como relação a si'). O sistema do 'ouvir-se-falar' através da substância fônica - que se dá como significante não-exterior, não-mundano, portanto, não-empírico ou não contingente - teve de dominar durante toda uma época a história do mundo, até mesmo produziu a ideia de mundo, a ideia de origem do mundo a partir da diferença entre o mundano e o não-mundano, o fora e o centro, a idealidade e a não-idealidade, o universal e o não-universal, o transcendental e o empírico, etc. (Derrida, 2008: 9, grifo nosso)

O filósofo francês nos convoca, contra a prioridade fonética do Ocidente, a pensar a relação entre linguagem e técnica de modo diferente. Na direção oposta aos desdobramentos da mimese, como 
indicado na crítica do Fedro, Derrida (2008) preocupa-se com o ponto de vista da escritura como uma técnica distinta, e não a técnica como conceito que guarda a linguagem escritural.

Técnica a serviço da linguagem: não recorremos aqui a uma essência geral da técnica que já nos seria familiar e que nos ajudaria a compreender, como um exemplo, o conceito estreito e historicamente determinado da escritura. Ao contrário, acreditamos que um certo tipo de questão sobre o sentido e a origem da escritura precede ou pelo menos se confunde com um certo tipo de questão sobre o sentido e a origem da técnica. É por isso que nunca a noção de técnica simplesmente esclarecerá a noção de escritura. (Derrida, 2008: 10, grifo nosso)

Em outras palavras, a "gramatologia", ou ciência do gramma, é o saber da hipérbole da escritura, da posição que toma o conceito de escritura como aquilo que excede e compreende o conceito de linguagem. O que se constrói, pois, no caminho de volta, de Wiener à Górgias, da Cibernética à Sofística, é uma dimensão "revolucionária" no século XX, mas que Aristóteles anteviu na Retórica e na Poética. No fundo, esta relação percorre mesmo o Medievo, guardadas as proporções do Neoplatonismo do longo período de luzes sob o conceito de Deus e não mais de Ser. Além disso, tal dimensão é "fundadora" da Modernidade, seja esta entendida como fruto do Renascimento Cultural dos séculos XIII e XIV, seja compreendida como fruto do Renascimento Artístico dos dois séculos seguintes. Entre estes séculos, a adaptação da velha prensa do ourives às artes gráficas permite ao mundo propagação da ideia da extensão da linguagem como partícipe do humano. "Coisas" agora (definitivamente) "falam". As artes bibliográficas são, desde a sua constituição (até onde o horizonte arqueológico nos leva), metáforas vivas das filosofias da ausência.

Se, com Auroux (1998), compreendemos que a "escrita" e, posteriormente, a "gramatização", representam um passo decisivo de edificação de um princípio tecnológico (e não técnico, ou seja, de reflexão sobre a técnica, o logos sobre o artefatual), estamos diante do 
ocaso da aporia das "filosofias da presença", que tanto incomodam. Chegamos ao que chamamos "gramatologia de ordem inversa", ou uma "filosofia da ausência", melhor expressada como, a nosso ver, "filosofia das formas simbólicas" à moda cassireriana. Poderíamos ainda reconhece-la desta maneira: "uma gramatologia da pós-escrita, a gramática a posteriori." (Saldanha, 2012: 382)

\section{MEDIAÇÕES ORDINÁRIAS: A INVENÇÃO MAQUÍNICA DA "MEDIAÇÃO HUMANA"}

\section{[...] logocentrismo: metafísica da} escritura fonética. (DERRIDA, 2008: 3)

Recoloquemos agora o fonocentrismo no escopo dos estudos informacionais. Percebamos como, ao mesmo tempo, se a filosofia da presença é a marca do Ocidente filosófico contra os processos de mediação técnica, o desenvolvimento das artes (técnicas) de mediar e, posteriormente, o delineamento da epistemologia da Ciência da Informação entre os séculos XIX e XX, nos diz o contrário, bem como os discursos para uma filosofia da informação na contemporaneidade. Nosso percurso, de fundo hipotético-filosófico deliberadamente bibliofílico, coloca-nos no eixo oposto: o logocentrismo, a centralidade da fala, do sopro, ou, ainda, a pneumo-constante é, do lado de cá (estudos informacionais de mediação), sustentada por uma racionalidade gráfica (gramatical, materialista, técnica). Desde que se entende como arte, ou quando se afirma ciência, como em Gabriel Peignot (1802a, b) e Paul Otlet (1934), nosso modo de pensar a mediação tem, se não uma relação unívoca, uma co-constituição permanente entre o elemento técnico da linguagem e o elemento linguístico do humano.

É preciso enfatizar, em nosso giro hermenêutico, que Derrida (2008), no entanto, reluta insistentemente contra esta tessitura epistêmica -talvez não reconhecendo tal processo histórico-científico, mesmo tanto questionando a noção de "livro". Em sua visão, a elaboração histórica do conceito de livro (fundante para o pensamento 
informacional entre mundo francófono e anglófono), mesmo diante da longa revisão de E. R. Curtius (1996), onde a magnitude do conceito oriundo do biblion é lançada, responde menos ao materialismo da linguagem e seu maquinismo da ausência, e mais ao estado de presença da filosofia fonocêntrica.

Em 'O simbolismo do livro', este belo capítulo de $A$ literatura europeia e a Idade Média latina, E. R. Curtius descreve com uma grande riqueza de exemplos a evolução que vai do Fedro a Calderón, até parecer 'inverter a situação' pela 'nova consideração de que gozava o livro'. Contudo, parece que esta modificação, por importante que seja em efeito, abriga uma continuidade fundamental. Como acontecia com a escritura da verdade da alma, em Platão, ainda na Idade Média é uma escritura entendida em sentido metafórico, isto é, uma escritura natural, eterna e universal, o sistema da verdade significada, que é reconhecida na sua dignidade. (Derrida, 2008: 18-19, grifo nosso)

A noção de "livro", no pensamento do filósofo francês, responde, pois, pela mesma "natureza" ou "essência" da phoné.

A escritura natural está imediatamente unida à voz e ao sopro. Sua natureza não é gramatológica, mas pneumatológica. É hierática, bem próxima da santa voz interior da Profissão de Fé, da voz que se ouve ao se entrar em si: presença plena e veraz da fala divina a nosso sentimento inferior. (Derrida, 2008: 20-21, grifo nosso)

$\mathrm{Na}$ crítica fonocêntrica de Derrida (2008), ao se reportar à totalidade, a noção de livro no Ocidente "perde" sua "materialidade primordial" (a condição de fragmento vegetal do biblion) e "reencontra" a idealidade da Beleza dialetizada no Fedro de Platão.

A idéia de livro é a idéia de uma totalidade, finita ou infinita, do significante; essa totalidade do significante somente pode ser o que ela é, uma totalidade, se uma totalidade constituída do significante preexistir a ela, vigiando sua inscrição e seus signos, 
independentemente dela na sua idealidade. A idéia do livro, que remete sempre a uma totalidade natural, é profundamente estranha ao sentido da escritura. É a proteção enciclopédica da teologia e do logocentrismo contra a disrupção da escritura [...]. (Derrida, 2008: 21-22, grifo nosso)

O que, em nossa visão, Derrida (2008) dispensa é a condição material (principalmente do materialismo simbólico) e o embate filosófico do logos contra o onto - ou seja, ao se dedicar ao logos como aproximação ao onto, realiza uma leitura ontológica (metafísica) da escritura a partir do logos platônico, ao invés de realizar uma leitura logológica da escritura contra o onto parmenídico. A dispensa leva consigo o apagamento da sofística, e com ela a força performática do materialismo linguístico (e o metamaterialismo linguístico dos registros do conhecimento, da escritura, do livro) ao longo da Antiguidade, do Helenismo, do Medievo e da Modernidade, bem como carrega em seus argumentos as filosofias contemporâneas da linguagem, como aquela dedicada à linguagem ordinária, que permitem, em certos momentos, inclusive se apoiadas em parte da própria visão do filósofo francês, pensar uma racionalidade mediadora não apenas dependente da phoné presencial. Em outras palavras, Derrida (2008) investe na crítica ao logos de "Sócrates, aquele que não escreve" e não se aproxima do logos do "Aristóteles, aquele que lê".

É o encontro com a Sofística e com a construção do trivium, ou das artes liberais da linguagem, a saber, lógica, retórica e gramática -trivium este destacado pelo próprio Derrida (2004) em $\mathrm{Pa}$ pel-Máquina- que podemos perceber que a filosofia da ausência pode ser reconhecida como o nó teorético na elaboração epistemológico-histórica dos estudos informacionais, tendo a mediação como uma de suas centralidades.

Na visão de Cassin (2005, p. 63), o movimento sofístico muda a direção da teoria do conhecimento do onto para o logos, ou seja, do "ser pelo ser" ao "discurso pelo discurso do ser". Dizer o ser é criá-lo. A poiesis sofística estabelece a fundamentação do discurso como potência e matéria da condição humana. A logologia, e não a 
ontologia, se coloca como a epistemologia que nos desvela (e, antes, edifica) o mundo. Em suas palavras, "Logologia: o discurso faz o ser, o ser é um efeito de dizer. Em um caso, o de fora se impõe e impõe o que se diga; no outro, o discurso produz o de fora." Deste modo, para aquém e além de performance, o discurso dos sofistas é algo "inteiramente performativo". É criador, organizador e preservador do "real". "Ele é demiúrgico, fabrica o mundo, faz com que advenha - e teremos, logo mais, a exata medida disso com a cidade e a política”. (Cassin, 2005: 63)

Tal logos sofista é, ainda, antes de um organon, instrumento de demonstração, um pharmakon, ou seja, um remédio para o desenvolvimento das almas e da cidade. Como o verdadeiro e o falso da dialética são dissolvidos no discurso, a possibilidade de uma ambivalência não-lógica se define, resultando em uma questão de valor. Neste contexto, o físico é substituído pelo político, a política é legitimada como partilha, e seu sentido se aproxima da bomologia, ou do acordo discursivo. (Cassin, 2005). Mas se não nasce para o organon, termina enquanto tal: o materialismo da linguagem (também oral) cria e ordena; e a escrita, como afirma Auroux (1998), implica o "reflexivo" que pressupõe a "ordem".

Derrida (1991), agora não exatamente em sua crítica ao logocentrismo, recorda que a logografia era a arte de compor discursos (e escrevê-los, em boa parte), para que outros o pronunciassem, sem que a presença do autor se fizesse, ou seja, sem qualquer responsabilidade pelo uso do e pelas consequências de seu discurso. Este seria o "homem da não presença", e, por extensão (socrático-platônica) "da não-verdade", que resulta na questão inicial da "escritura" como "encenação" e da "incompatibilidade do escrito e do verdadeiro". (Derrida, 1991: 12)

Estabelece-se aqui uma visão crítica não apenas ao logos da phoné vertical (de um para todos, o discurso contra o diálogo), mas o problema (principal) dos "logói en bibliois", da "escritura, o phármakon", como "descaminho" (Derrida, 1991: 16). A visão de Platão, ou de Sócrates contra Fedro, é fundamentada, segundo Derrida (1991), no acontecimento presencial do autor, na performance viva do pai. O livro é a palavra morta, o discurso putrefato, na medida 
em que se distancia de seu construtor. Neste sentindo, dir-se-ia que a "especificidade da escritura se relacionaria, pois, com a ausência do pai" (Derrida, 1991: 22). O logos platônico, diferentemente do logos da sofística, dar-se-ia na responsabilidade da presença do pai diante dos ouvintes.

Este virtus do logos como o discursivo, e não o dialético (o lógico), é que parece não estar em Derrida $(2008,2004)$ à primeira vista, em sua crítica ao fonocentrismo. A possibilidade de reinterpretação da posição do filósofo francês talvez esteja no reconhecimento da phoné também como matéria, e, com isto, da relevância do "materialismo linguístico" e seus desdobramentos, como caso do "metamaterialismo linguístico" dos registros do conhecimento.

O "imperialismo do logos" diante da sofística necessita ser tomado como distinto do "imperialismo da phoné". Tratar do logos discursivo dos sofistas é também tratar do futuro discurso registrado, contra o qual o Fedro argumenta na ameaça do grafo. Esta possibilidade interpretativa ganha margens de discussão quando percebemos a preocupação de Derrida (2004) com o universo da escrita e seu diálogo com o trivium e o quadrivium.

Para o filósofo francês, deve-se compreender a noção de gramática "a partir de referências ao trivium e ao quadrivium [...]" e das concepções de "máquina da letra, máquina a letra (gramma), máquina de escrever." (Derrida, 2004: 126). Derrida (2004) busca a relação entre linguagem e tecnologia, linguagem e o metamaterialismo linguístico, e provoca a possibilidade de uma visão técnico-virtual do "engenho dos traços" como uma máquina de produção do mundo.

Não se diz que a máquina é uma gramática do texto. Nem que a gramática do texto é uma máquina. Uma é como a outra, a partir do momento em que a gramática é isolada da retórica (retórica performativa ou retórica cognitiva, retórica dos tropos), de acordo com uma outra distinção. Determina-se a máquina a partir da gramática, e vice-versa. Isolada de sua retórica, enquanto suspensão da referência, a gramática é puramente formal. Isto va- 
le em geral: nenhum texto pode ser produzido sem esse elemento formal, gramatical ou maquinal. (Derrida, 2004: 126, grifo nosso)

Se retiramos a retórica da gramática, de fato, nos resta o formal e o formalizável. Contudo, em contextos sócio-culturais, explicitamente, em cenários onde o político se impõe, como a cidade, não poderá existir a gramática sem a retórica. E tais "máquinas" edificadas com as engrenagens de retórica, gramática e (também) lógica (ou seja, as máquinas do trivium), são igualmente "humanas" e "maquínicas", "naturais" e "artificiais", são o homem e o artefato em um só espaço-tempo. Separar os processos de mediação deste complexo é não perceber que mediar é, fundamentalmente, um processo maquínico, posto que humano. Em outros termos, a mediação é uma poética e se estabelece na complexidade do trivium.

Em sua primeira nota de rodapé no Papel-Máquina, o filósofo francês, agora próximo de Auroux (1998), esclarece a questão que nos permite pensar simultaneamente o discurso oral sofística da Grécia Clássica e o desenvolvimento de sistemas em rede na contemporaneidade: "O algoritmo é, na verdade, uma 'característica', consiste em caracteres escritos”. (Derrida: p. 4). O logos entendido no bojo do trivium é uma técnica de fabricar o "humano". É preciso, pois, entender que a "mediação técnica" cria o problema de compreensão da "mediação humana", e não o contrário. Esta inversão (sofística em sua historicidade) se não é fundamental para os diversos domínios do conhecimento, é fundante do que hoje tratamos por estudos informacionais. Não "acontece" uma Ciência da Informação sem a "mediação técnica"; e é através dela que podemos pensar o "humano", não como "separação", mas como uma espécie de espelho turvo, dinâmico, em ação contínua dos reflexos que se desencontram para revelarem-se em verossimilhanças, e não em identidades. 


\section{O SIMBÓLICO NAS MEDIAÇÕES ORDINÁRIAS: COMO FAZEMOS COISAS COM MATÉRIAS SIMBÓLICAS}

O advento da escritura é o advento do jogo. (DERRIDA, 2008: 8)

Apesar da permanente preocupação com a phoné, Derrida (1991) nos abre a margem de compreensão de que, mesmo em Platão (como ver-se-á também em Aristóteles), existe uma certa "necessidade logográfica", que é análoga à "necessidade biológica", dentre outras. Trata-se de abordar o logos como um zôon, ou seja, dado no mundo material, vivo e animado. Em nosso ponto de vista, o pensamento sobre as práticas ordinárias (a linguagem ordinária conforme o Wittgenstein das Investigações Filosóficas) permite-nos superar a crítica "humana" ao "maquínico", ou sua "separação", e adentrarmos o modo "maquínico" de ver o humano que, no fundo, se transparece como, simplesmente, uma maneira de compreender a maneira como nós pensamos através das máquinas da linguagem.

Esta possibilidade interpretativa das práticas de mediação recairia diretamente dentro dos conceitos de simbólico e simbolismo, e levar-nos-ia para o pensamento davalloniano. O teórico francês dos estudos de mediação busca uma razão simbólica para compreender as práticas mediadoras e seus mediadores. $\mathrm{O}$ aporte convoca a identificação de dois "gestos simbólicos", o primeiro respondendo por operações de instauração de relações entre "mundo do visitante" e o "mundo da ciência", mundo dos saberes; o segundo gesto respondendo pela expansão da noção de mediação a partir da "dimensão simbólica do funcionamento midiático". (Davallon, 2007: 5-6)

Outra vez retornamos ao conceito de "gramática", estratégico em Derrida (2008) e em Auroux (1998), como também em Wittgenstein (1979, 2005). Adentramos agora o "maquinário" da pragmática. Para Wittgenstein (1992a), a procura pela expressão metafísica ou mentalista dos conceitos resulta numa busca de construções pré-determinadas na linguagem que não podem exis- 
tir. A linguagem é fruto de uma espécie de "jogo", que define regras mutantes no tempo-espaço e que se consolida (se equilibra) a partir de "gramáticas", vinculadas a "formas de vida" distintas. A elaboração de um significado está, deste modo, inserida dentro da "engrenagem" da gramática - em suas palavras, - "o uso da palavra, na prática, é o seu sentido”. (Wittgenstein, 1992a: 118).

Apropriado o pensamento "gramatical" wittgensteiniano no encontro Auroux-Derrida, na potência criadora do logos cassiniano, podemos pensar na construção de ferramentas ordinárias de elaboração do sentido e, como consequencia, de um "real simbólico", ou, ainda, de um "real" que só pode ser condicionado enquanto tal a partir do simbolismo provocado pelo maquinismo linguístico. Este maquinismo, antes de ser "racional", é "ação", é "uso", estabelece-se na pragmática de elaboração cotidiana do mundo.

A filosofia da linguagem ordinária de Wittgenstein, fundada em suas Investigações filosóficas, estabelece que nossos modos de ver, de criar, de perceber o real não estão condicionadas a nenhuma estrutura a priori. Todo o decurso da pretensa "natureza humana" enquanto espaço reflexivo da filosofia é constituído a partir da reflexividade da linguagem - como uma "gramática" aurouxiana celebra.

Contra a representação - objeto comum da reflexão dos estudos de mediação -, Wittgenstein (1979) procura um modo de compreender o real como ação. Sua ação é, no entanto, da ordem da linguagem. O modo desta "atuar" se dá segundo os jogos entre comunidades distintas que podemos, retornando ao centro de nosso debate, o conceito de "mediação", entendermos como não apenas a "ação humana", a ação do eu-mediador. Antes, contra uma dicotomia das filosofias da presença e da ausência, podemos abordar a "ação maquínica" do humano como um "efeito da linguagem", o que nos reintegra ao logos sofístico de Cassin (2005). Os "gestos simbólicos" davallonianos ganham peso na análise das instrumentalizações midiáticas não vistas como "isto", mas como parte do "eu".

Este movimento permanente das "mediações ordinárias", quando interpretadas à luz da epistemologia da Ciência da Informação, mais especificamente em um escopo epistêmico onde a "escrita" e as tec- 
nologias da linguagem quaisquer sempre terão uma espécie de centralidade, conduz-nos objetivamente a uma "filosofia das formações simbólicas", isto é, nos convoca ao aprofundamento das práticas de mediação como fruto de uma ação simbólica do humano-maquínico. Auroux (1998) demonstra que a reflexividade da "escrita" (da técnica da escrita!) tem como um de seus aportes a formalização. $O$ processo de formalização é, antes de unicamente lógico (como demonstra a organização epistêmica do trivium), também gramatical e retórico (mas principalmente gramatical, se entendida a gramática como técnica de comunicação a partir dos símbolos). Assim, através da invenção da escrita

Há uma literalização - abre acesso a um pensamento simbólico - parece-nos que a simbolização é algo de mais profundo que o arbitrário batismo. A literalização manifesta o fato de que todo elemento da cadeia linguística é substituível por outro em circunstâncias dadas. O simbolismo supõe então duas coisas: a substitubilidade dos signos, que é uma propriedade intrínseca à linguagem, e a equivalência sinóptica das formas, que é uma manifestação da razão gráfica. (Auroux, 1998: 74-75, grifo nosso)

O resultado é a identificação da super-ação do humano com o desenvolvimento de processos de simbolização, fruto, na verdade, de gramatizações plurívocas, no seio das trocas de jogos de linguagem cotidianos. Estas super-ações colocam as possibilidades de mediação como fruto direto da linguagem já como uma técnica de onde provém as margens de definição do humano, e não o contrário. Estamos diante, quando afirmamos a existência (e os problemas de tal existência) de uma "mediação técnica", daquilo que podemos, no fundo, nos definir: o animal symbolicum de Enrst Cassirer (1994), e não aquele pretensamente $a$ priori racional. Não se trata, pois, de retirar do "racional" sua condição, mas de reconsidera-lo, pois a "própria mitologia não é uma massa grosseira de superstições e ilusões crassas. Não é meramente caótica, pois possui uma forma sistemática ou conceitual". (Cassirer, 1994: 49) 
Contra uma constituição metafísica ou mentalista do real, que nos conduziria a uma análise representacional das práticas de mediação, tendo apenas como solução crítica o ataque à mediação técnica, a relação entre as mediações ordinárias e as formas simbólicas posiciona a "mediação" no escopo de uma filosofia da cultura, que, colocada como um eixo de compreensão da epistemologia da Ciência da Informação, demanda-nos uma noção de "mediação" concebida como um desdobramento gramatical da linguagem.

A tarefa verdadeira mais profunda de uma filosofia da cultura, da linguagem, do conhecimento, do mito etc. parece consistir, precisamente, em erguer este véu, em sair da esfera mediadora do simples significar e designar, e retornar à esfera original da visão intuitiva. Por outro lado, o órgão específico de que dispõe a filosofia se opõe à solução desta tarefa. À filosofia, que só se realiza na precisão do conceito e na clareza do pensamento 'discursivo', o paraíso da mística, do imediato puro, está vedado. (Cassirer, 2001: 74, grifo nosso)

Da noção de "mediação" na filosofia, desvelada por uma "filosofia das formas simbólicas", podemos pensar uma noção de "mediação" no escopo dos estudos informacionais não apegada aos modos de separação do reprentacionismo, que isola, por exemplo, sujeito e objeto, presença e ausência, humano e técnica. A possibilidade da tecnologia da escrita e, posteriormente, da gramatização, conforme anunciado por Auroux (1998), concebe, de um lado, a alteridade refletida (o "isto-eu"), de outro, a possibilidade de existência de uma futura epistemologia da Ciência da Informação.

No primeiro caso,

[...] o impulso do saber linguístico tem uma de suas origens no fato de que a escrita, fixando a linguagem, objetiva a alteridade, quer esta provenha da Antiguidade, quando é preciso ler um texto que não corresponde mais ao estado da língua, ou da novidade, quando se trata de decifrar um texto que não se conhece antes ou de transcrever uma outra língua. (Auroux, 1998: 78, grifo nosso) 
No segundo caso, o do condicionamento técnico-linguístico de aparecimento dos estudos informacionais, a escrita produz "o aparecimento de técnicas autônomas e inteiramente artificiais, assim como um dos primeiríssimos ofícios da linguagem na bistória da bumanidade, o do escriba, atestado entre os egípcios quanto os sumérios." (Auroux, 1998, p. 78, grifo nosso). Ao escriba, mediador (técnico), acrescentemos o bibliotecário, a biblioteca, os sistemas bibliográficos, as práticas biblioteconômico-bibliográficas, a mediação - além de toda sorte de predicações contemporâneas manifestadas pelo "informacional".

Se a "metafísica constituiu um sistema de defesa exemplar contra a ameaça da escritura" (Derrida, 2008, p. 125), a construção da epistemologia dos estudos informacionais e, mesmo, das abordagens recentes da filosofia da Ciência da Informação, tomam a direção oposta. As declarações epistêmicas de Gabriel Peignot (1802a, b) e Paul Otlet (1934) demonstram que o desenvolvimento do pensamento informacional segue na via contrária deste modo de perceber o real. A condição bibliológica de uma epistême peignotiana-otletiana pressupõe, necessariamente, não apenas a escrita como fundação, mas como co-partícipe do humano. Trata-se da não separação, da não aceitação, das dicotomias representacionistas, dentro/fora, humano/ técnica.

Parece-nos que no escopo contemporâneo dos estudos informacionais, da hermenêutica em Rafael Capurro (1992) ao quadro de reflexões neodocumentalistas, como aquelas oriundas de Frohmann (2004, 2011), de Day (2005) e de Buckland (1991, 1997), sugerem a compreensão de destituição desta força representacionista. O ponto nevrálgico está na reconsideração não do "humano" sob a "técnica", mas da poiesis plural da linguagem refletida na escrita (técnica) que, sendo "humana", possibilita o acontecimento do próprio "humano". O espaço de consideração da informação como uma coisa, ou como documento, como artefato, é o terreno onde podemos encontrar o eu-mediador presente no interior da epistemologia da Ciência da Informação. 


\section{REFLEXÕES FINAIS: PARA AQUÉM DA PRESENÇA}

A época do logos, portanto, rebaixa a escritura, pensada como mediação de mediação e queda na exterioridade do sentido. (DERRIDA, 2008: 15)

As ações informacionais de mediação quando encaradas enquanto práticas ordinárias nos levam à redução dos falsos antagonismos entre mediação humana (mediação da presença), e mediação técnica (mediação da ausência). Pensar na centralidade (não única, não imóvel, não ideal) do uso de tecnologias da linguagem como modo de compreensão do mundo informacional é perceber a necessidade de aprofundamento na noção de "humano", sem a contraposição homem-máquina.

A possibilidade de compreensão do campo informacional como saber gramatológico, mas de ordem distinta da gramatologia de Derrida (2008), torna-se um percurso crítico-histórico para esta distinção. Em termos pontuais, chamamos a atenção para o que interessa na análise da mediação no plano epistemológico dos estudos informacionais: quem manipula o gramma, a linha, o traço (quem programa as gramáticas, ou seja, as tecnologias) para mediar?

Uma vez apreendida a linguagem (o complexo técnico da linguagem) como tecnologia, mais precisamente, uma vez consolidada a visão de que a gramática ou os processos de gramatização definem-nos no espaço grafado como "um outro reflexivo", nos "participam do mundo como alteridades" (relação esta provocada não só pela escrita, mas, mesmo, pela performance gramático-lógico-retórica da materialidade da phoné), podemos identificar a existência de uma invenção da "mediação humana" equivocada no campo. Trata-se da construção do conceito da filosofia da presença, "mediação humana", para uma dupla racionalidade: a) compor outra unidade conceitual, "mediação técnica"; b) colocar esta última como antítese da primeira ou, no mínimo, seu polo problemático.

Pelas possíveis relações aqui discutidas entre a "gramatologia" em Derrida (2008) e a "gramatização" em Auroux (1998), relações 
estas costuradas principalmente a partir de Cassin (2005) e Wittgenstein (1979), compreendemos que os estudos informacionais são dedicados à reflexão sobre as tecnologias da linguagem, seu uso, seus desusos, suas consequências, seu desenvolvimento. $\mathrm{O}$ argumento nos leva à seguinte assertiva: ao contrário do percurso que parece "natural", retiramos da "mediação técnica" (ponto de vista da gramatização aurouxiana) a necessidade de tratar da "mediação humana" enquanto filosofia da presença (ponto crítico da gramatologia derridaiana), para então "reduzirmos" a potência das mediações técnicas.

Fato curioso pode estar, nesta interpretação, na noção de "humanismo informacional". Parece-nos clara a intenção teorética na compreensão sobre mediação de fundar o eu-mediador na metafísica da presença mediadora, enquanto que o isto-mediador, a máquina, é o fora, a ausência possível. É compreensível tal confusão, contempladas (principalmente) as relações sócio-históricas que evocam os riscos (e, em alguns casos, o "pânico") diante de distintas tecnologias da linguagem (estas, por sua vez, tomadas, em dados momentos, como a revolução em si, e não interpretadas historicamente). Exemplos como a possibilidade imediata de perda de postos de trabalho (profissional e acadêmico) e outros, de vulto maior, como a extinção da própria episteme em questão, são modelos de tais equívocos. Sabe-se que, por exemplo, a corrida pela tradução automática e o desenvolvimento dos sistemas eletrônicos de informação levantou, em diferentes discursos, a partir de meados do século XX, a possibilidade de identificação da ineficácia de uma Ciência da Informação no futuro. Esquece-se que por "humanismo informacional" podemos simultaneamente tratar: a) da questão de formação, ou seja, da história das disciplinas e dos enfoques culturalistas da educação de bibliotecários; b) da questão puramente técnica, a história do desenvolvimento de tecnologias de representação e fluxo da informação.

Ao nos depararmos com o "materialismo" cassiniano da Retórica, reconhecemos o vazio da predicação "humano" na edificação do conceito de "mediação humana". Se a "gramática" em seu sentido filosófico e, mesmo, no sentido pedagógico do trivium, trata-se de uma 
máquina de produzir efeitos materiais no mundo, o "humano" da noção de "mediação" não está na anterioridade do ser cognoscente, nem (ainda) na anterioridade do onto, mas no a posteriori do logos, ou do discurso em seu jogo, em sua performance. A técnica, por sua vez, não é um "fora", não é também um a priori, mas é co-condição do humano expresso na intersubjetividade ordinária da epistemologia da Ciência da Informação.

O que está "ausente", na filosofia da mediação técnica, não é o "humano", mas a nossa incapacidade de perceber que ali só pode existir ele, o "humano" (fruto e semente do maquínico), sem o qual nem máquina nem homem poderiam ser concebidos, posto que o reflexo que potencialmente os separa é a possibilidade da reflexividade que os inventa na técnica. A escrita, sombra perigosa da filosofia da ausência, esta mancha no espelho do humano, seria, para os estudos informacionais, a primeira possibilidade, o limite teorético, de definir a incoerência de uma "natureza da mediação humana". Aqui, nessa epistême, mediar é gramatizar.

$\mathrm{O}$ medo de nos vermos como máquinas e, mais ainda, como produtos da técnica (e, ainda, "prisioneiros" do maquínico), é o terror de nos depararmos no espelho homem-máquina com a barbárie humana, e não com uma barbárie maquínica. Este ponto de vista hermenêutico-crítico também está na Antiguidade: Aristóteles não só concebe para muitos, com as práticas bibliológicas de seu fazer filosófico, a Filologia (a Gramática), mas também reestabelece o papel da Retórica, retirando desta a barbárie técnica que ela pretensamente ensejaria. Em outras palavras, logo após a força do fonocentrismo platônico, a escola peripatética relaciona-se pontualmente com um certo logos da Bibliologia, sendo o Estagirita "pai" de um certo Helenismo, cultura não coincidentemente "centrada na palavra escrita”. E a mediação técnica alexandrina nada mais é do que uma autêntica ars grammatica. 


\section{BIBLIOGRAFÍA}

Auroux, S. (1998), A Filosofia da linguagem, Campinas: Unicamp.

Parábola.

(2009a), Filosofia da linguagem, São Paulo: (2009b), Revolução tecnológica da gramatização, Campinas: Unicamp.

Buckland, M. K. (1991), "Information as Thing", en Journal of the American Society of Information Science, $\mathrm{v}$. 42, núm. 5, pp. 351-360, jun.

(1997), "What is a Document?", en Journal of the American Society for Information Science, v. 48, pp. 804-809.

Capurro, R. (2000), "Hermeneutics and the Phenomenon of Information", en Mitcham, Carl (Ed.). (2000), Metaphysics, Epistemology and Technology. Research in Philosophy and Technology, New York: Elsevier. v. 19. pp. 79-85, disponible en: <http://www.capurro.de/ ny86.htm>. Fecha de acesso: 18 jul. 2007.

(2008), "Pasado, presente y futuro de la noción de información", en Encuentro internacional de expertos em teorias de la información: un enfoque interdisciplinar, 1., 2008, León. [Anais...]. León: Proycto: BITrum,

(2003), "Epistemología y ciencia de la información", en Encontro nacional de pesquisa em ciência da informação, 5., 2003, Belo Horizonte, Anais... Belo Horizonte: Escola de Ciência da Informação da UFMG. 
Capurro, R. (1992), "What is Information Science for? A Philosophical Reflection", en Vakkari, P.; Cronin, B. (Ed.). Conceptions of Library and Information Science; Historical, Empirical and Theoretical Perspectives. In: International Conference for the Celebration of 20th Anniversary of the Department of Information Studies, University of Tampere, Finland. 1991, Proceedings... London, Los Angeles: TaylorGraham, pp. 82-96.

Cassin, B. (2005), O efeito sofístico: sofística, filosofia, retórica e literatura, São Paulo: ed., 34.

Cassirer, E. (2011), "A filosofia das formas simbólicas"; Terceira parte: Fenomenologia do conhecimento, São Paulo: Martins Fontes.

(1994), Ensaio sobre o homem: introdução a uma filosofia da cultura humana, São Paulo: Martins Fontes. (2004), A filosofia das formas simbólicas; Segunda Parte: O pensamento mítico, São Paulo: Martins Fontes.

(2001), A filosofia das formas simbólicas; Primeira parte: A linguagem, São Paulo: Martins Fontes.

Curtius, E. R. (1996), Literatura européia e idade média latina, São Paulo: Hucitec.

Day, R. (2005), "Poststructuralism and Information Studies", en Annual Review of Information Social Science and Technology (ARIST), v. 39, pp. 575-609.

Day, R. (2001), The Modern Invention of Information: Discourse, History and Power, Illinois: Southern Illinois University Press.

- (2009), "Revisiting "What is a Document?" en Journal of Documentation, v. 65, núm. 2, pp. 291-303. 
Davallon, J. (2007), "A mediação: a comunicação em processo?", en Prisma.Com: revista de Ciência da Informação e da Comunicação do CETAC, núm. 4, pp. 1-34, jun, disponible en: http://prisma.cetac.up.pt/edicao_n4 _junho_de_2007/, (Fecha de consulta: 10 enero 2014).

Derrida, J. (2008), Gramatologia, São Paulo: Perspectiva.

(2004), Papel-máquina, São Paulo: Liberdade.

(1991), A farmácia de Platão, São Paulo: Iluminuras.

Frohmann, B. (2004), "Documentation Redux: Prolegomenon to (Another) Philosophy of Information", en $\mathbf{L i}$ brary Trends, v. 52, núm. 3, pp. 387-407, win.

(2011), "Reference, Representation, and the Materiality of Documents", en Colóquio científico internacional da rede MUSSI. 2011, Anais... Toulouse: Université de Toulouse 3 .

Haller, R. (1990), Wittgenstein e a filosofia austríaca: questões, Tradução Norberto de Abreu e Silva Neto, São Paulo: ed. USP.

Oliveira, T. de (2002), "Alguns comentários sobre o Tractatus", en Wittgenstein, L. (2002), Tratado Lógico Filosófico; Investigações filosóficas, Tradução M. s. Lourenço. $3^{\text {a }}$ ed. Lisboa: Fundação Calouste Gulbenkian, pp. XI-XXXII.

Otlet, P. (1934), Traité de documenatation: le livre sur le livre: théorie et pratique, Bruxelas: Editiones Mundaneum.

Peignot, G. (1802a), Dictionnaire raisonné de bibliologie, tomo I, París: Chez Villier.

(1802b), tomo II. París: Chez Villier. 
Saldanha, G. S. (2012), Uma filosofia da Ciência da Informação: linguagem, organização dos saberes e transgramáticas, Tese-Instituto Brasileiro de Informação em Ciência e Tecnologia (IBICT); Faculdade de Administração e Ciências Contábeis (FACC); Universidade Federal do Rio de Janeiro (UFRJ), Rio de Janeiro.

Wiener, N. (1989), The human Use of Human Beings: Cibernetics and Society, Londres: Free Association Press

Wittgenstein, L. (2005), Observações filosóficas, São Paulo: Loyola.

(2002), Tratado Lógico Filosófico; Investigações filosóficas, Tradução M. S. Lourenço. $3^{\mathrm{a}}$ ed. Lisboa: Fundação Calouste Gulbenkian.

(1968), Tractatus logico-philosophicus, São Paulo: Ed. Nacional: Ed. da Universidade de São Paulo, 152 p. (Biblioteca universitaria. Serie 1. filosofia; v. 10). (1980), Culture and Value, Oxford: Blackwell. (1979), Investigações Filosóficas, $2^{\mathrm{a}}$ ed., Tradução de José Carlos Bruni, São Paulo: Abril Cultural. (1992a), O livro azul, Lisboa: Ed. 70. (1992b), O livro castanbo, Rio de Janeiro: Edições 70. 


\title{
La mediación en bibliotecología/ciencia de la información/documentación. Algunas reflexiones
}

\author{
Miguel Ángel Rendón Rojas \\ Universidad Nacional Autónoma de México
}

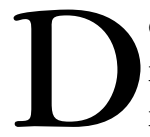

espués de haber conocido las propuestas que los autores nos presentaron a lo largo de este libro, ha llegado el momento de sugerir algunas reflexiones sobre lo leído y vislumbrar algunas consecuencias que de ellas se desprenden. En primer lugar, con respecto al trabajo de la Dra. Ortega, considero importante resaltar como un acierto la distinción que realiza entre los términos 'documental' y 'documentario', más aún en el contexto en el que nos encontramos de querer clarificar el concepto de 'mediación' en el campo de la Bibliotecología/Ciencia de la Información/Documentación. El primer vocablo: 'documental' es un adjetivo derivado de un sustantivo, de un objeto, de una cosa: el documento; mientras que el segundo, 'documentario' se deriva de un proceso, de una acción realizada sobre el documento, forzando el término y quizá no muy acorde con la lingüística -lo reconocemos-, podríamos decir que deriva de un verbo: 'documentar' en el sentido de 'convertir en documento'. Pero ese convertir se debe entender dentro del contexto de la disciplina, lo que utilizando el marco teórico que manejo, significa introducir ese objeto documental como objeto documentario en el Sistema Informativo Documental. Lo anterior significa que un objeto es documento, 
ya sea directamente por intención de su autor, un libro, artículo, ponencia, carta o fotografía por ejemplo; o no por intención inmediata de su autor sino por la actividad realizada en él por un especialista -crítico de arte, arqueólogo, investigador criminalista, biólogo, etc.- que dedujo información a partir de una pintura de la Virgen María, una vasija de barro maya, una pistola, o una mariposa respectivamente; es manipulado, trabajado por el profesional de la información documental a través de actividades técnicas, tecnológicas, científicas o empíricas, desde su valoración, adquisición, análisis, descripción, representación, organización y disposición en el marco institucionalizado por la ciencia correspondiente: Bibliotecología/Ciencia de la Información/Documentación. Es decir; un libro, por ejemplo, que ya es en sí un documento desde su creación, si no pasó por una actividad documentaria, indudablemente sigue siendo un documento, que nos conduce al mundo de la información, pero un documento en una librería, en una colección privada en la casa de un personaje, en un almacén, puede ser un recuerdo, un objeto de lujo, una demostración de un status intelectual, un soporte para una puerta, pero no es un documento bibliotecológico (o un documento de la Ciencia de la Información o de la Documentación). Dos ejemplares de un mismo libro -título- pueden ser dos documentos distintos, si uno de ellos pertenece a una colección de un biblioteca (y pasó todo un proceso documentario que modificó su ser) y el otro es un libro que pertenece a alguien en particular.

Ya anteriormente habíamos declarado como una característica del documento el hecho de que "[...] es el producto de la actividad bibliotecológica" (Rendón Rojas, 2005:125), que lo que hace el profesional de la información documental "[...] se asemeja a la acción de un demiurgo que crea el mundo informativo documental" (Rendón Rojas y Herrera Delgado, 2010b:49) y que "[...] el cosmos documental [nace] regido por el orden, nacimiento mediado por la actividad del sujeto". (Rendón Rojas y Herrera Delgado, 2010a:16) Ahora finalmente podemos decir, gracias a las aportaciones de Cristina Ortega que esas acciones mencionadas por las que se creaba el documento y a las que me refería a falta de un mejor término 
como "actividad bibliotecológica", "acción de un Demiurgo", "actividad de un sujeto" es la mediación, la actividad documentaria.

Otro punto a resaltar en el trabajo de Cristina Ortega es la introducción del momento lingüístico y comunicacional en el concepto de mediación. De esta manera, inserta el aspecto humano en el proceso de mediación además de los elementos procedimentales científico-técnicos. En efecto, la actividad documentaria no representa una acción eminentemente técnica, cuya ejecución está reservada a especialistas que trabajan de manera competente y precisa con su material, como lo harían los cirujanos al realizar una operación a corazón abierto; los químicos que combinan las substancias necesarias en la proporción correcta para obtener las reacciones que requieren; los farmacéuticos al preparar un medicamento con los miligramos exactos de sus componentes; o los contadores que calculan ingresos, egresos y deducen y pagan diversos impuestos.

La mediación en el campo informativo documental es también un proceso comunicacional en el que se involucran símbolos -textos, documentos-; significados, sentidos, y también sujetos. Estos últimos inmersos en un contexto biográfico personal, psicológico, social, histórico, cultural, y finalmente existencial (haciendo su ser, formándose a través de elecciones), lo que implica salir de los límites de lo dado, lo nomológico, lo estructural, lo sintáctico-combinatorio, lo funcional, y por lo tanto lo repetitivo, secuencial, predictivo; para pasar al mundo de los deseos, los valores, las perspectivas, las interpretaciones, las intenciones, lo siempre abierto a distintas posibilidades, a lo inacabado, a la diferencia, a lo abierto y a lo dinámico. En este nivel de interacciones significativas entre sujetos, la mediación aparece, además de acciones procedimentales guiadas por una racionalidad estratégica, como un diálogo entre sujetos, guiado consiguientemente por una racionalidad dialógica y todo lo que esto implica: cumplir con las pretensiones de validez propuestas por Habermas: verdad, rectitud, adecuación o inteligibilidad (Habermas, 1999:64) y con las condiciones generales de simetría entre los hablantes, y excluir toda coacción sometida a una regulación especial y producción de argumentos pertinentes. (Habermas 1999: 46-47). 
Al mismo tiempo y como consecuencia de introducir el diálogo en el proceso de mediación, el sujeto-usuario se convierte en interlocutor y adquiere un papel central al ser quien finalmente actualiza el sentido del documento. Es por ello que en esa mediación-diálogo, para que realmente sea mediación debe existir una sintonía, sincronía y simpatía entre todos los actores: usuario, texto, autores, profesionales de la información documental, o utilizando la terminología de Gádamer, llegar a una fusión de horizontes hermenéuticos entre ellos, con lo cual se alcanzaría la comprensión. ${ }^{1}$ Ese ciclo del documento que empieza con su creación y se cierra con su uso, así como el concepto de satisfacer necesidades de información, desde una visión hermenéutica, se condensan en la comprensión, producto del diálogo. Pero ese final se puede convertir potencialmente en inicio. La nueva información que se obtuvo, el conocimiento que se construyó, el sentimiento o emoción que se formaron, cambian el horizonte del usuario y ahora como pre-comprensión conforman un nuevo horizonte hermenéutico, desestabilizando la fusión alcanzada, por lo que es necesario buscarla y encontrarla una vez más. Eso y que los agentes dialogantes van cambiando hacen que el diálogo sea continuo.

Finalmente quisiera comentar brevemente la posición de Cristina Ortega sobre los términos "documento" e "informativo documental", optando ella por el primero y el autor de estas líneas por el segundo. Personalmente considero que sobre los términos no se debe discutir sino sobre los conceptos, aunque la Dra. Ortega enfatiza que Una propuesta terminológica consistente y propia es no sólo rentable sino necesaria para un proyecto de fundamentación y consolidación científica. Según mi opinión el análisis conceptual de ambos términos nos acercará y mostrará la afinidad conceptual.

La Dra. Ortega prefiere seguir la base terminológica fecunda que puede ser identificada en la literatura otletiana y desarrollada en las siguientes décadas en torno al término 'documentación', porque

1 "Comprender es siempre el proceso de fusión de estos presuntos horizontes para sí mismos. Gadamer, H. G. (1999) Verdad y método 1. Salamanca: Sígueme. 376-377. 
la forma española 'informativo-documental' y la forma francesa 'information-documentation' pueden considerarse redundantes, ya que 'documento' es un término que abarca la noción de soporte físico y de información o contenido atribuido.

En efecto, 'documento' como concepto ya contiene lo informativo en sí, por lo que siguiendo a Kant en su división de los juicios, el enunciado 'el documento es informativo' es un juicio analítico porque el predicado ya se encuentra en el sujeto; pero que paradójicamente puede ser a posteriori. Ya vimos que existen varios niveles de 'ser documento'; un documento puede ser tal por decisión del autor, por un análisis de un especialista en una disciplina concreta, por interpretación del usuario o por la mediación del profesional de la información documental. Es en este último caso que aparece el documento propiamente dicho en nuestra área (Bibliotecología/Ciencia de la Información/Documentación). Es en esa acción documentaria en la que se trabaja con la información del documento, se crea nueva información sobre la información de ese documento y se le prepara para ser informativo. Ahí está lo informativo documental. Los otros documentos en otros contextos fuera del sistema informativo documental siguen siendo informativos, por supuesto, pero no se trabajó con su información para que quedaran listos para ser informativos. Al mismo tiempo tal vez el usuario no necesita la información en sí, a la que accede gracias a ese documento que se le ofrece, sino que esa información se encuentra un medio sine qua non para alcanzar otros objetivos: conocimiento, prueba, requisito burocrático, exaltación estética, etc. Lo informativo se queda en el área, en ese proceso de mediación que estamos analizando, y por eso preferimos el término informativo-documental. Podemos agregar que uno de los seguidores de Otlet que desarrollaron la propuesta otletiana de Documentación, el Dr. José López Yepes, en su última obra optó por el título Ciencia de la Información Documental y no "Documentación" o "Ciencia de la Documentación", lo que muestra lo atractivo que resulta la fusión de lo informativo con lo documental (López Yepes, 2015).

Por lo que atañe al segundo capítulo, Dimensiones de los procesos de mediación del conocimiento. Contribución para un dis- 
curso interdisciplinario en ciencias de la información, llama la atención la intencionalidad de los autores de fundamentar ontológicamente la mediación al dedicarle un apartado a la "Dimensión ontológica de la mediación”. Esa postura ontológica le otorga la primacía al ser, a la realidad objetiva porque finalmente el ser, [es] el principal mediador. En este sentido estos autores concuerdan con la idea que he defendido frente a los subjetivismos tan extendidos en la filosofía posmoderna. Necesitamos un ancla, un punto de apoyo que nos proporcione un soporte firme desde donde poder iniciar nuestro análisis y es el ser quien cumple con esa función. Pero al mismo tiempo Pirela y Delgado se alejan de una ontología metafísica, inerte, última, completa, terminada y abstracta. Por el contrario, el ser que tienen en mente es un ser ligado a lo humano y al lenguaje, por lo que es dinámico y en continuo hacerse. Así pues, a partir de esa mediación fundamentada ontológicamente, se toma como segundo momento o, más bien, como otro aspecto de la misma mediación, el diálogo, que es donde se encuentran los diversos actores de ese proceso, y se actualiza esa mediación al participar todos en el acto comunicativo que debe conducir a la comprensión, al buscar todos juntos la información, o al construir conocimientos, en un intercambio de ideas, acciones y roles entre los autores, así como sus textos, los profesionales de la información documental, los usuarios, la sociedad como tal, y también sus instituciones.

Asimismo puede resaltarse la idea de expresar la necesidad de realizar un análisis multifacético de la mediación para poder comprenderla, lo que a su vez conduce directamente a la exigencia de un acercamiento interdisciplinar y transdisciplinar para construir el conocimiento en el campo informativo documental. En este trabajo la mediación que nos interesa es, como los autores la designan, la mediación informacional, pero que a su vez incluye, como ya lo hemos visto con el trabajo de Cristina Ortega, el aspecto comunicativo, que ella denomina, siguiendo a la escuela francesa, "info-comunicacional", mostrando así la unión de esas dos dimensiones: informativa y comunicativa. De esta manera encontramos una coincidencia en los tres autores sobre esa idea, lo que a su vez nos convence de 
la importancia del momento comunicativo en el campo informativo documental.

Por otro lado resulta interesante que Pirela y Delgado centren su atención en la 'mediación del conocimiento'. En última instancia el trabajo bibliotecológico/documental/informacional tiene un matiz explicativo de corte mediador y comunicativo cognitivo. Incluso las bibliotecas, archivos, centros de documentación, servicios de información son vistos como organizaciones de conocimiento. Es decir, durante todo su discurso consideran al conocimiento, lo cognitivo, como el fin último, la intencionalidad determinante que dirige el proceso de la mediación. El hecho de que se incluya el análisis educacional de la mediación se explica en gran medida por esa visión teleológica cognitiva.

Tal vez ese énfasis en el conocimiento se deba a su adscripción institucional, ya que su trabajo como profesores e investigadores lo realizan en el "Centro de Investigación y Desarrollo en Tecnologías del Conocimiento", aunque la insistencia en la construcción del conocimiento como objetivo final de la mediación parezca mostrar su convencimiento de ese hecho. Desafortunadamente no queda del todo claro lo que se entiende por conocimiento, aunque siguiendo el concepto tradicional de éste, aparentemente estamos frente a un hecho intelectual, un conocimiento proposicional cuyo análisis se remonta en el Teetetes de Platón. De acuerdo con Luis Villoro:

Casi todos los estudios analizan el conocimiento proposicional, es decir, el que se refiere a un hecho o situación expresados por una proposición. [...]

En pocos temas filosóficos podemos encontrar un consenso tan general como la definición de "saber". La gran mayoría de los autores contemporáneos que escriben sobre teoría del conocimiento, por diferentes que puedan ser sus enfoques y posiciones teóricas, coinciden en el análisis de ese concepto, con variantes, sin duda, en la manera de expresarse. Ese análisis puede acudir a una larga tradición que se remonta hasta el Teetetes de Platón. Podríamos designarlo como el "análisis tradicional" de saber." (Villoro, 2008: 14). 
Como se recordará, en su diálogo Platón afirma, a través de su personaje Teetetes, que el conocimiento es una creencia (opinión) verdadera. $^{2}$ Pero aunque esa condición es necesaria no es suficiente. Para que una creencia verdadera sea conocimiento se necesita además que sea justificada; es decir, se tengan razones suficientes que la fundamenten. Villoro presenta la siguiente traducción de ese pasaje: "La creencia verdadera por razones ( $\mu \varepsilon \tau \alpha \dot{\alpha} \lambda$ ó $\gamma \mathrm{ov}$ ) es saber, la despro-

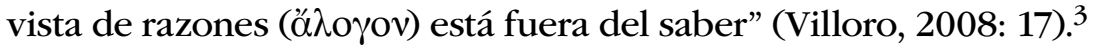

En resumen: $S$ sabe que $p$ supone tres condiciones:

1] $S$ cree que $p$,

2] " $p$ " es verdadera,

3] $S$ tiene razones suficientes para creer que $p$ (Villoro, 2008: 18). ${ }^{4}$

Ahora bien, si el conocimiento se expresa a través de una proposición, y ésta es una expresión lingüística que puede ser verdadera o falsa, entonces este concepto de conocimiento está relacionado con una visión que privilegia el conocimiento intelectual, lógico e instrumental. Esto está muy cerca del concepto de Documentación de "ciencia de la ciencia" de López Yepes en su versión de 1995, (López Yepes, 35-35).

Como lo expresan Pirela y Delgado: El enfoque cognitivo enfatiza en la potencialidad que tienen los alumnos para que se con-

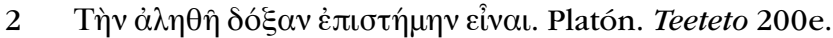

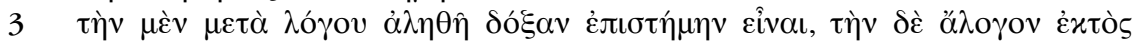

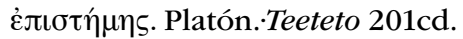

4 Se podrá argüir que existen serias objeciones al concepto de conocimiento como creencia verdadera y justificada con los contraejemplos de Gettier (1963) y otros semejantes en los que se muestran casos en que la justificación no conduce al conocimiento sino el azar. Como este libro no es un trabajo de Teoría del Conocimiento no nos extenderemos mucho en los argumentos y contraargumentos sobre este problema. Sólo diremos que la justificación debe estar relacionada con la verdad de la proposición. Lo que nos interesa es el hecho de que se establece un nexo necesario entre conocimiento-razón-intelecto. 
viertan en aprendices estratégicos, es decir, en actores que aprendan cómo aprender y cómo resolver problemas. Al menos como aquí lo expresan, estamos frente a una racionalidad estratégica y un conocimiento instrumental. Lo que nos lleva a reflexionar sobre la posible continuación, en la llamada sociedad de la información, del proyecto de la modernidad y de la razón ilustrada.

Sin embargo, no debemos olvidar que la razón, llamémosla intelectual; no es la única que podemos identificar, otros pensadores nos han mostrado que también existen otros tipos de razón o racionalidad como la dialógica, la práctica, la crítica, la dialéctica, la histórica, la técnica, así como distintos tipos de saberes, no necesariamente conocimientos verdaderos y justificados, como el saber técnico, prudencial, religioso, estético, entre otros. La intencionalidad del sujeto no se reduce al conocimiento intelectual, también encontramos valores, deseos, afectos, sentimientos. Por consiguiente esa acción mediadora informacional no conduce siempre y necesariamente al conocimiento intelectual, puede ser que lleve a alguien que visita una fonoteca, a un documento sonoro que le produzca una emoción y sentimiento estético; o a un libro que excita la imaginación y sirve para la recreación; o a un texto que puede llevar a una conversión de su actitud ante la vida o incluso a una experiencia mística, etcétera.

También es por eso que el nexo información-conocimiento no es simple y unívoco; incluso puede decirse que la información no es única en su naturaleza y forma; podemos encontrar una información $e i$ dética que nos lleve al mundo de las ideas, juicios, raciocinios, teorías; pero también puede haber una información estética en el sentido etimológico de "sensible", que nos conduzca al mundo de los sentimientos y las emociones. Ciertamente como resultado de la mediación, el profesional de la información documental le ofrecerá siempre al usuario una información eidética que el primero produjo con su actividad, para que el usuario pueda tener acceso al documento y, a través de él, a la información que le interesa para obtener el saber qué quiere.

Muchas veces se necesita que la información que se obtenga no sea solamente veraz, -para qué me sirve que me den un documento en el que se afirma que la tierra gira alrededor del sol, aunque 
sea verdad eso no lo necesito- sino que la información sea oportuna, relevante y completa, en algunas ocasiones hasta información sobre errores o rumores.

Por las discusiones en el seminario y lo expresado por Pirela y Delgado no dudamos que esa apertura de su concepción de conocimiento a otros tipos de saberes esté ahí de manera implícita, aunque considero que es necesario detallarla y discutirla más ampliamente.

En cuanto al tercer capítulo Mediação e filosofia da ausência: $a$ invenção gramatical da "mediação bumana" e super-ação do bumano podemos decir que un elemento a resaltar en las propuestas expuestas es la llamada de atención que nos hace el Dr. Saldanha para estar alertas ante la contraposición presencia-ausencia derivada de la dicotomía humano-técnica. Dentro de esa concepción lo humano es la presencia, el ser, la racionalidad; mientras que la técnica es su opuesto. Sin embargo después de su análisis el Dr. Saldanha concluye que no debe darse esa oposición contradictoria, porque finalmente la técnica es humana y hace al humano; así como el humano crea la técnica y es producto de la técnica. Siguiendo a Derrida, descalificar casi de manera a priori la técnica como no humana o casi antihumana es un error metafísico derivado de la visión platónica de la distinción realidad-apariencia; serno ser; presencia-ausencia que tiene su correlato en idea-materia, y de ésta, aplicada al lenguaje, resulta logos-escritura. Utilizando la amplitud del término logos que significa al mismo tiempo idea, pensamiento, razón pero también palabra y discurso, se culpa al logocentrismo, la centralidad del habla, de conducir al sentido del ser como presencia, relegando a la escritura, al fin y al cabo material y no unida directamente al ser, sino al habla, como algo secundario. Además de que la escritura, creada como técnica para hacer perenne lo que se dice, también conduce a concebir a la técnica como ausencia de ser. Lo que produce la apariencia, la ausencia, no es posible que sea el ser, sino que también debe de ser una especie de ausencia, de no ser.

Sin embargo es un hecho que la Bibliotecología/Ciencia de la Información tiene que ver directamente con los libros, los documentos, así como con la técnica, como acciones de mediación. Por lo 
que concebir al libro o documento como algo secundario, limitante de la oralidad, y a la técnica como contrapuesta a lo humano, es tener una mirada muy pobre de esa ciencia informativo documental. Es por eso que es necesario reconsiderar esa forma de pensar.

Aunque concordamos con la conclusión, consideramos que el precio a pagar es alto. La causa, según palabras de Saldanha, de esa dicotomía "[...] es el papel de representación del lenguaje”, por lo que si se le quita a éste ese papel, se soluciona el problema. En efecto, ese logos -palabra que nos lleva al logos- razón, el cual a su vez finalmente nos conduce al ser, es el culpable de todos los malos entendidos. Por consiguiente, para romper esa cadena sólo es necesario desechar el soporte, el punto de donde parte todo, en este caso el ser, y todo lo demás cae por su propio peso. De esta manera Derrida proclama que no hay referente que designar y finalmente il n'y a pas de hors-texte (No hay nada fuera del texto):

[Las consideraciones metodológicas dependen] en cuanto a la ausencia del referente o del significado trascendental. No bay fuera del-texto [...] Lo que hemos intentado demostrar [...] es que dentro de lo que se llama la vida real de esas existencias "de carne y hueso", más allá de lo que se cree poder circunscribir como la obra de Rousseau, y detrás de ella, nunca ha habido otra cosa que escritura; [...] el presente absoluto, la naturaleza, lo que nombran las palabras "madre real", etc., se han sustraído desde el comienzo, jamás han existido; que lo que abre el sentido y el lenguaje, es esa escritura como desaparición de la presencia natural (Derrida, 1986: 202-203).

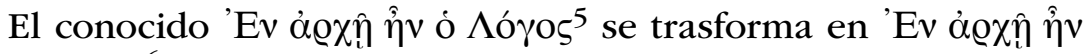

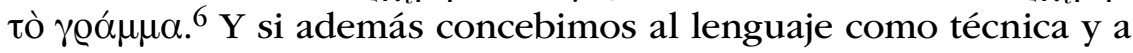
la escritura como una técnica fundacional, queda claro que el problema de menospreciar a la técnica queda sin fundamento y surge la necesidad de profundizar en la idea de lo humano.

Desde nuestro ya conocido realismo dialéctico hermenéutico (Rendón Rojas, 2013: 280-281) nos es difícil renunciar a la realidad

5 (En arjé en o logos -En el principio era el logos).

6 (En arjé en to gramma-En el principio era el grama). 
del ser y además proclamar al lenguaje como una técnica. El reto entonces es conciliar esa conclusión partiendo de un marco teorético menos relativista y conservando la idea del lenguaje, no como técnica sino como modo fundamental del ser humano.

Indudablemente la representación del lenguaje no se entiende como la relación de un símbolo con un eidos, una esencia, una idea metafísica preexistente, completa, terminada y eterna. El mundo de los significados y sentidos no existe ante rem -antes de las cosasen un тóлоร оv@аvós (topos uranós), inmaterial, suprasensible, metafísico. Efectivamente, la función significativa de los signos se crea en acciones a partir de su uso en un juego dentro de una forma de vida. Sin embargo, una de las reglas de ese juego indica que se debe crear el vínculo de ese signo con ese objeto o sentido creado y cada vez que se use, se recree el vínculo o se agregue uno nuevo si hay una nueva interpretación, pero de tal manera que no se traicione el vínculo inicial. ${ }^{7}$

El signo 'adherido' a un soporte que lo hace perdurable (y siguiendo la terminología de Derrida lo convierte en trazo, buella) sigue siendo signo que se usa con un vínculo que lleva al referente o al sentido, no al signo fonético. (Esto vale incluso para signos sonoros que reproducen otros signos sonoros del habla, los primeros representan ideas aunque al mismo tiempo conducen a reproducir so-

7 Un caso específico que nos atañe en este mismo libro es el uso del vocablo 'documentario' introducido por Cristina Ortega con un significado nuevo pero haciendo alusión a 'documento'. Es una nueva regla en nuestro juego de lenguaje de especialistas en Bibliotecología/Ciencia de la Información, quienes no compartan nuestro juego no nos comprenderán, asimismo no podemos decir que el significado de 'documentario' como una idea platónica completa ya existía ad aeterno; al contrario, se acaba de construir e introducir en nuestro discurso, pero desde ahora y en este juego del lenguaje concreto, la palabra 'documentario' -en forma oral o escrita- representa una acción que un profesional de la información documental realiza sobre y con el documento, en cualquier etapa del ciclo de circulación del documento -desde su creación hasta su uso para la satisfacción de necesidades de información del usuario- para que dicho ciclo se realice. De este modo a elaboração de um significado está [...] inserida dentro da "engrenagem" da gramática [morfologia y sintaxis] y nosotros agregaríamos, así como de la semántica. 
nidos articulados). En el alfabeto fonético ciertamente un grafema ${ }^{8}$ simboliza un fonema, y el conjunto de grafemas forman una palabra y finalmente un texto. Pero aunque el referente del grafema sea un sonido, éste no es su significado, es por eso que la lectura no es descifrar grafemas en fonemas, sino en encontrar la idea que contiene el texto o la palabra escrita completa. Debido a que el significado de lo escrito son ideas y no sonidos flatus vocis, es posible que esos trazos sigan siendo vivos y, en el caso de los libros, como lo expresara Ortega y Gasset, estén "[...] en potencia, diciendo siempre lo que

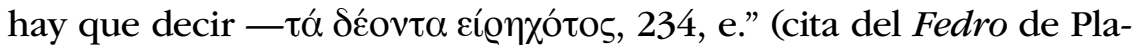
tón), (Ortega y Gasset, 2005: 88) aunque también dispuestos a decirnos algo nuevo según los interpelemos.

Ahora bien, ya que el ser humano no es un ser natural, no es acabado, sino que se debe hacer, " $<<[\ldots]$ no es por naturaleza lo que debe ser >>; por eso necesita de la formación”, (Gadamer, 1999: 41) entonces construye su mundo, el mundo de la cultura y al mismo tiempo se autoconstruye como culturizándose. La creación de su mundo cultural ocurre dotando de sentido a la realidad a través del lenguaje De este modo el lenguaje sea oral o escrito no es sólo una técnica, sino el modo en que el ser humano va construyendo su mundo de sentidos y accede a él. De esta manera no importa que el lenguaje sea escrito, este último no es sinónimo de ausencia, de no ser o de falta de ser, porque no es el sirviente de lo oral, simplemente es el signo de lo fonético, su ser en otro, estático, muerto. También es lenguaje vivo, dinámico, creador de sentidos.

Si la creación o más propiamente, la construcción del mundo humano se produce al darle sentido al mundo circundante a través del lenguaje, entonces desde una visión puramente instrumentalista podemos decir que el lenguaje, si se quiere, es la técnica primigenia, la técnica fundacional. A semejanza del Dios creador del Génesis que a través de su palabra crea el universo, la palabra es su técnica, o la del demiurgo que pone orden en el caos siguiendo la

8 1. m. Ling. Unidad mínima e indivisible de la escritura de una lengua. Diccionario de la lengua española. http://lema.rae.es/drae/?val=grafema 
proporción, también utiliza 'su técnica'. Así pues la técnica se convierte en algo humano, uma técnica de fabricar o "bumano". De esta manera la técnica no se confronta con lo humano, al contrario, lo crea. No es ausencia, no ser, apariencia. Toda esa valoración negativa de la técnica es el resultado de la visión platónica que divide al mundo de las ideas como el verdadero y al mundo material como apariencia. Por consecuencia, todo lo que ayude a construir lo material: escritura, técnicas, es opuesto al verdadero ser; pero si nos apartamos de esa visión dicotómica, evitamos sus consecuencias. É preciso, pois, entender que a "mediação técnica" cria o problema de compreensão da "mediação humana", e não o contrário. El olvido del ser, la enajenación, el fetichismo, ocurren cuando las creaciones someten a su creador y se vuelven contra él.

Aún más, aunque puede concebirse el lenguaje como la técnica primigenia, Saldanha habla más bien, mais precisamente, [das] técnicas da linguagem; es decir, aplicaciones de la técnica a esa técnica fundacional, que no son otra cosa que las actividades documentarias de las que nos hablaba la Dra. Ortega. Gracias a esas actividades que finalmente vienen a ser mediaciones de información, se prepara al documento para su uso: recrear sentidos y significados para el usuario, lo que significa, extendiendo el alcance de las leyes de Ranganathan y sustituyendo 'libro' por 'documento', crear las condiciones necesarias para que el documento sea usado, el documento tenga su lector, el lector su documento, y se le ahorre tiempo al lector.

Y de ahí podemos concluir junto con Saldanha:

Pensar na centralidade (não única, não imóvel, não ideal) do uso de tecnologias da linguagem como modo de compreensão do mundo informacional é perceber a necessidade de aprofundamento na noção de "humano", sem a contraposição homem-máquina.

Para concluir, además de lo ya expresado, creemos que podemos realizar una analogía de lo que entendemos por mediación en el campo informativo documental, con algunas acciones de mediación en otras áreas, lo que nos ayudará a clarificar un poco más ese concepto. 
Una de esas áreas es el campo de la psicología, concretamente en la propuesta del análisis transaccional de la personalidad. En esta teoría dinámica de la personalidad se concibe una interacción entre los tres componentes de la personalidad: adulto, niño, padre, en el intercambio que se tiene entre las personas. Lo que nos interesa, dejando a un lado toda la teoría psicológica, es el concepto de transacción. De acuerdo con Berne "Es llamada transacción porque cada participante gana algo, y por eso es por lo que se involucra en ello" (Berne, 1977: 35).

Entonces el intercambio entre los participantes en la transacción de manera activa, consciente y voluntaria propicia que llegen a un convenio, un trato donde los dos ponen de su parte y llegan a un arreglo benéfico para ambos. Lo mismo podemos decir de la mediación política. Los actores tienen sus intereses, y los defienden, pero toman en cuenta a su interlocutor. De manera análoga en la mediación informativa documental los participantes: el profesional de la información documental que con su actividad documentaria reconstruye el documento y lo prepara para un público; y el autor que ofrece su texto porque quiere comunicar su mensaje; el mismo texto que puede contener su propia versión de verdad que difiere del autor porque dice más de lo que el autor quería y creía; y el usuario que con su interpretación recrea la información del autor, del texto y puede agregar la suya propia; todos con ese diálogo, transacción, comunicación, acción dinámica, ganan. El documento se usa, el autor encuentra su lector; el lector su documento; el profesional de la información documental se realiza como tal al realizar su trabajo y cumplir su función social; y el usuario satisface sus necesidades de información.

Pero como en toda realidad humana, siempre el resultado final depende de la voluntad y apertura de los sujetos. Ese ganar para todos no es el final feliz optimista que invariablemente sucede. En cada momento está en juego el hecho de que se realice o no. El autor puede mentir, plagiar, utilizar un lenguaje oscuro para parecer profundo y ocultar su falta de ideas; el profesional de la información documental puede no mostrar interés, ser apático y no cumplir con su labor de manera adecuada; el usuario puede tener el 
documento en sus manos y no tomarse el trabajo de adentrarse en el mundo de la información que éste le abre; la sociedad o el Estado pueden no coadyuvar de manera suficiente a ese mundo informativo documental... En fin, diversos factores pueden intervenir y obstaculizar para que ese ciclo social de la información en el que participa la mediación, se cierre y empiece nuevamente. Todo finalmente depende de nosotros, de nuestras elecciones y acciones.

\section{BIBLIOGRAFÍA}

Berne, E. (1977), ¿Qué dice usted después de decir hola? Barcelona: Grijalvo.

Derrida, J. (1986), De la gramatología, México: Siglo XXI.

Gadamer, H. G. (1999), Verdad y método I. Fundamentos de una hermenéutica filosófica, Salamanca: Sígueme.

Gettier, E. (1963), "Is Justified True Belief Knowledge?", Analysis 23 (1963): pp. 121-123, disponible en http:// www.ditext.com/gettier/gettier.html. (Fecha de consulta: septiembre de 2015).

Habermas, J. (1999), La teoría de la acción comunicativa I, Madrid: Taurus.

Lopez Yepes, J. (2015), La ciencia de la información documental, México: Universidad Panamericana.

(1995), La documentación como disciplina: teoría e historia, $2^{\mathrm{a}}$ ed., Pamplona: Eunsa.

Ortega y Gasset, J. (2005), Misión del bibliotecario, México: CONACULTA, fundación José Ortega y Gasset.

Platón, Théétète, ou de la science, 198a-210d., Traduction française Victor Cousin. v. 2 y 5, disponible en: http:// remacle.org/bloodwolf/philosophes/platon/cousin/theet ete6.htm 
Real Academia Española (2001), Diccionario de la lengua española. 22 $2^{\mathrm{a}}$ edición. (Fecha de consulta: septiembre de 2015).

Rendón Rojas, M, Á. (2005), Bases teóricas y filosóficas de la bibliotecología, Segunda Edición, México: UNAM-CUIB.

(2013), El objeto de estudio de la bibliotecología/ documentación/ciencia de la información. Propuestas, discusión, análisis y elementos comunes, Miguel Ángel Rendón Rojas, Colaborador y coordinador, México: UNAM, Instituto de Investigaciones Bibliotecológicas y de la Información. 295 p.

- y Herrera Delgado, Berenice (2010a), "Bases filosóficas de la organización de la información”, en Perspectivas em Ciência da Informação. v. 15, núm. 1, Belo Horizonte, Minas Gerais, Brasil: Escola de Ciência da Informação (ECI), Universidade Federal De Minas Gerais (UFMG), pp. 3-17.

y Herrera Delgado, Berenice (2010b), "El profesional de la información documental. Eidos-noumeno-identidad versus -skia-fenómeno-imagen", en Revista Mexicana de Ciencias de la Información, SLP: UASLP, ECI. v. 1. núm. 2. pp. 40-52.

Villoro, L. (2008), Creer, saber, conocer, México: Siglo XXI. 
La mediación en el campo informativo documental. Instituto de Investigaciones Bibliotecológicas y de la Información/UNAM. La edición consta de 100 ejemplares. Coordinación editorial, Carlos Ceballos Sosa; Revisión especializada, Francisco Xavier González y Ortiz; Cotejo y corrección de pruebas, Zyanya Benavides Reyes; Formación editorial, Mario Ocampo Chávez. Fue impreso en papel cultural de 90 g. México, D.F. Se terminó de imprimir en el mes de marzo de 2017, en los talleres AGYS Alevin, S.C., Retorno de Amores, No. 14, colonia Del Valle, C.P. 03100, delegación Benito Juárez, Ciudad de México. 